\title{
Cladistic systematics of the genus Amphimallon (Coleoptera: Scarabaeidae: Melolonthinae)
}

\author{
OLIVIER MONTREUIL \\ UPRES-A 8043 CNRS, Laboratoire d'Entomologie, Muséum National d'Histoire Naturelle, 45 rue Buffon, 75005 Paris, France; \\ e-mail: o.montr.@mnhn.fr
}

Key words. Cockchafer, Melolonthidae, Amphimallon, cladistic systematics, species-group, new species, synonymy

\begin{abstract}
A phylogeny of fifty-eight cockchafer species belonging to the genus Amphimallon Berthold, 1827 is proposed, based on sixty-five morphological characters. The cladistic analysis provides seventy-two equally parsimonious trees. The genus $A m p h i-$ mallon is redefined and species-groups are introduced and defined: $A$. pini-group (seven species), $A$. vernale-group (five species), $A$. solstitiale-group (seven species), A. arianae-group (two species), A. peropacum-group (one species), A. fuscum-group (eleven species), $A$. naceyroi-group (seven species), A. majale group (five species), A. lusitanicum-group (six species). Other species previously placed in Amphimallon are considered species incertae sedis in this paper: amphibolum Peyerimhoff, 1949, and a monophyletic group composed of six North African species: altifrons Baraud, 1971, julieni Baraud, 1972, melillanum Baraud, 1972, scutellare Lucas, 1846, subcristatum Fairmaire, 1879, subparallelum Escalera, 1913. Four new Amphimallon species are described: A. adanense sp. n. from Turkey, A. maniense sp. n. from Greece, $A$. jeannae sp. n. and $A$. safiense sp. n. from Morocco. The following taxonomic conclusions are proposed: A. seidlitzi Brenske, $1891=$ A. trisinuatum Reitter, 1902 syn. n.; Amphimallon jeannei (Baraud, 1971) comb. n.; Miltotrogus caucasicus Gyllenhal, 1817 comb. n.; Amphimallon vernale (Brullé, 1832) stat. n.; A. furvum (Germar, 1817) stat. n.; A. javeti Stierlin, 1864 stat. $\mathrm{n}$.
\end{abstract}

\section{INTRODUCTION}

The cockchafers of the genus Amphimallon Berthold, 1827 form one of the most important groups in western Palaearctic Rhizotrogini by the number of described taxa. This genus, considered in its traditional definition, is composed of more than sixty species (see Appendix 1) according to the most important recent works dealing with the western Palaearctic Melolonthidae (Medvedev, 1951; Baraud, 1985, 1992). The present paper adds species not studied bythe above authors and describes new species. These species are distributed from Morocco throughout Europe and central Asia to Siberia. In the Mediterranean Region they are absent from the southeastern part. In spring and summer, adults, and especially the males searching for females, are particularly active for a short time in the morning or in the evening twilight, flying above ground level of grassland or around the tops of the trees. Larvae feed upon plant roots. Some species, like A. solstitiale (L.), and especially A. majale (Razoumowsky), are known for causing severe damage, mostly to grass, in Europe (Régnier, 1939, 1940), but also in the United States (Schwardt \& Withcomb, 1943; Gambrell, 1946; Shorey \& Gyrisco, 1960), where A. majale has been introduced (Gambrell et al., 1942).

The genus Rhizotrogus Berthold, 1827 used to be considered as the closest genus to Amphimallon. Coca Abia $(1995,1998)$, in her taxonomic and phylogenetic study of Rhizotrogus, showed that these genera belong to a monophyletic group which also includes the western Palaearctic genera Monotropus Erichson, 1848, Geotrogus Guérin, 1842 and Amadotrogus Reitter, 1902. In the same work, Coca Abia supported the propositions of Nikolajev
(1987) and Baraud (1992), that Eriotrogus and Madotrogus, created by Reitter (1902) as subgenera of Amphimallon, should be considered as genera belonging to another Rhizotrogini-lineage.

Amphimallon and Rhizotrogus are traditionally distinguished by the number of antennal segments: 10segmented antennae in Rhizotrogus (Fig. 1), 9-segmented antennae in Amphimallon (Figs 2-3). However, some aberrant Rhizotrogus specimens with 9-segmented antennae have been found, and have wrongly been considered as Amphimallon (Baraud, 1977a; Montreuil, 1997), introducing a doubt in using this character to discriminate Amphimallon from Rhizotrogus. In her works, Coca Abia has proposed a new diagnostic character to separate both genera: the development of the sclerotized lateral apophyses in the endophallus. These apophyses are long and strong in Rhizotrogus (Fig. 4) and clearly reduced in Amphimallon (Fig. 5).

Amphimallon is a rather well-known group, but it has not been the subject of a complete recent revision, or of a phylogenetic study. The main purpose of this paper is to establish the phylogenetic relationships of Amphimallon species using a morphological approach, in order to revise systematics of the genus. The main groups of Amphimallon that can be defined by reference to this phylogeny are introduced. Taxonomic conclusions are also offered, and the description of four new species belonging to this genus are given in the last part of this paper: Amphimallon adanensis sp. n. from Adana, Turkey, separated from $A$. nigripenne Reitter, 1902; $A$. jeannae sp. n. from Morocco, until now confused with $A$. theryi Peyerimhoff, 1949; A. safiense sp. n. from Safi, Morocco, separated from $A$. litigiosum Fairmaire; and $A$. 

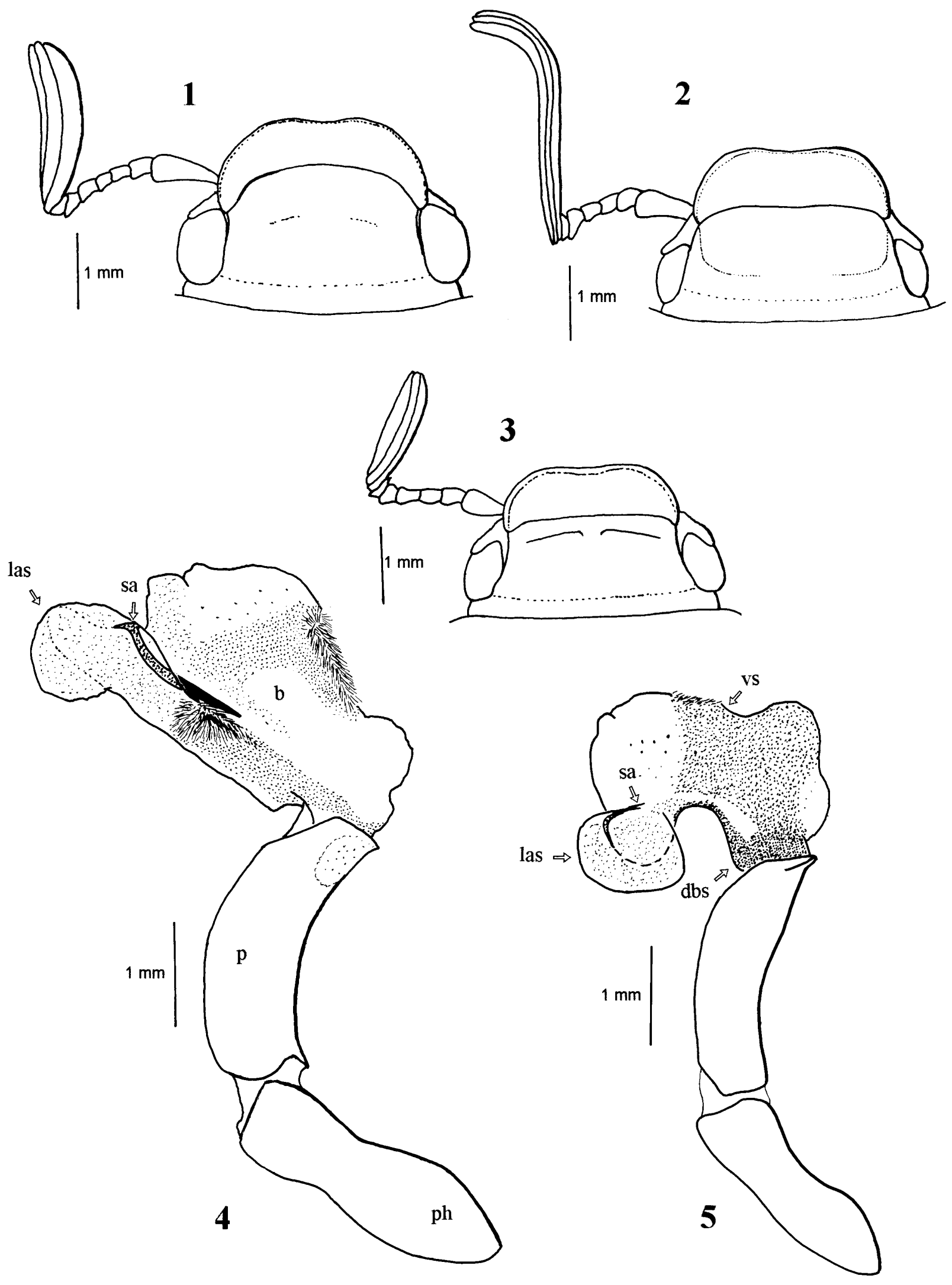

Figs 1-5. Amphimallon and Rhizotrogus. 1-3: Head (dorsal view; setae and punctation omitted). 1 - Rhizotrogus marginipes Mulsant; 2 - Amphimallon vitalei Luigioni; 3 -A. atrum (Herbst). 4, 5: Aedeagus and endophallus (lateral view; $\mathrm{p}-\mathrm{parameres;} \mathrm{ph} \mathrm{-}$ phallobasis; sa - sclerotized apophyses; $b$ - body of endophallus; las - lateral apical saccules; dbs - dorso-basal area of spicules; vs - ventral area of spicules). 4 - Rhizotrogus aestivus (Olivier); 5 - Amphimallon pygiale Mulsant. 
maniense sp. n., recently discovered in the Peloponnese, Greece.

\section{MATERIAL AND METHODS}

According to the recent general works which deal with Amphimallon (Medvedev, 1951; Baraud, 1985, 1992), and including described taxa not treated in these works, new taxonomic conclusions based on comparison of types and new species described in this paper, the genus Amphimallon Berthold, 1827 sensu auctorum is composed of sixty-seven species (Appendix 1). Fifty-eight Amphimallon species are considered in the phylogenetic analysis. The missing species which could not be studied in this work will be treated later in a general taxonomic revision in preparation.

In order to solve the phylogenetic relationships between the Amphimallon species considered, the cladistic method has been used, together with the principle of parsimony (Crisci, 1982; Forey et al., 1992; Darlu \& Tassy, 1993). The sixty-five morphological characters used in this phylogenetic analysis are listed in Appendix 2. They were examined on dry mounted adult specimens, mostly conserved in the Muséum National d'Histoire Naturelle, Paris, France (MNHN). Specimens of each species were observed directly, and specimens of common species were dissected and observed in lactophenol. Particular structures such as endophallus, digestive duct or bursa copulatrix were extracted from the abdomen and stained (Carayon, 1951, 1969). Only three characters have been found in structures because the females of many species are still unknown or were not available during this study.

The different states of each character were coded for each species in a data matrix with missing data and polymorphic characters scored "?" (Table 1). For each character, observed states at ingroup root are scored with " 0 " in the matrix after the analysis, in order to standardize the data presentation. In order to limit ad hoc hypotheses, the characters are unweighted, and multistate characters have been considered as unordered. The character states were polarized using outgroup comparison (Wiley, 1981; Nixon \& Carpenter, 1993). Three species belonging to two closely related genera (Coca Abia, 1995) were used as outgroups: Geotrogus inflatus (Buquet, 1840), Rhizotrogus aestivus (Olivier, 1789) and Rhizotrogus marginipes Mulsant, 1842. The data were analysed using a heuristic search routine with PAUP Version 3.1 (Swofford, 1992). The resulting trees were analysed with McCLADE (Maddison \& Maddison, 1993)

Taxonomic and nomenclatural conclusions proposed in this paper are based on the study of typical material deposited in the MNHN, or borrowed from the Hungarian Natural History Museum, Budapest, Hungary (HNHM, O. Merkl), from the Deutsches Entomologisches Institut, Berlin, Germany (DEIC, L. Zerche) and from the Naturhistoriska Riksmuseet, Stockholm, Sweden (NHRS, B. Gustafsson and J. Ferrer).

\section{RESULTS AND DISCUSSION}

Cladistic analysis generates seventy-two equally parsimonious trees, with a total length $(\mathrm{L})=223$ steps, consistency index $(\mathrm{CI})=0.4$ and retention index $(\mathrm{RI})=0.8$. The strict consensus of seventy-two trees is given in Fig. 6.

This consensus shows a main monophyletic resolved group which comprises most species of Amphimallon. The type-species of Amphimallon Berthold, 1827, Scarabaeus solstitialis L., 1758, belongs to this group. This group can be therefore considered as Amphimallon s. str. Unresolved phylogenetic relationships between this group, Rhizotrogus species, and seven species previously classified within Amphimallon (A. amphibolum and six species forming a monophyletic group called $A$. scutellare-group) are observed. This basal polytomy is the consensus of trees which show two main patterns. In the first pattern (Fig. 7), Rhizotrogus-species $+A$. scutellare-group $+A$. amphibolum form a monophyletic group presenting sister-group relationship with $A m p h i_{-}$ mallon. In the second pattern (Fig. 8), Rhizotrogusspecies $+A$. scutellare-group $+A$. amphibolum form a paraphyletic group. In both patterns, the A. scutellaregroup and A. amphibolum never occur within the Amphimallon s. str. These species have 9-segmented antennae like Amphimallon, but also have long and well developed sclerotized lateral apophyses in endophallus, like Rhizotrogus. The species belonging to the $A$. scutellare-group were sometimes placed in the particular subgenus Amadotrogus Reitter, 1902. The present analysis does not help to place these taxa, and they are here removed from Amphimallon and are temporarily considered species incertae sedis.

\section{Redescription of the genus Amphimallon Berthold, 1827}

Antennae 9-, exceptionally 8-segmented (character 8). The club, longer in the male than in the female, composed of three segments. Basal margin of pronotum enlarged or thin, but never lacking. Meso- and metasternum densely clothed with long pale hair-like setae. Inner edge of male protibiae tridentate, exceptionally with only one or two teeth; protibiae of females tridentate. Claws equal, outer side simple, ventral edges generally with a basal tooth. Sclerotized apophyses of endophallus feebly developed, thin and shorter than one third of the length of endophallus, sometimes absent (character 61). Basis of endophallus dorsally with a dense area of spicules which may or may not expand basally along the sides (character 63). Species of moderate size: $10-18 \mathrm{~mm}$. Basic colour yellow-brown, redd-brown or totally brown or black, pronotum often darker than elytra, rarely paler.

\section{Groups of Amphimallon}

Three lineages, based on the main clades in Fig. 6, can be recognized. Each lineage is composed of groups named from the species first described in the group. The species composition of each group is given and the main characters defining each group are presented. Unambiguous character changes are presented in Appendix 3. New taxonomic and nomenclatural considerations are added to this presentation when necessary.

\section{The $A$. solstitiale-lineage}

This lineage is composed of five monophyletic groups.

The $A$. pini-group

This group includes six species from southwestern Europe, A. gianfranceschii Luigioni, 1931, A. nigrum (Waltl, 1835), A. pini (Olivier, 1789), A. pygiale Mulsant, 1846, A. vitalei Luigioni, 1932, and A. vivesi Baraud, 1967. This group is one of the most characteristic and recognizable groups of Amphimallon. It corresponds to 
TABLE 1. Data matrix for sixty-one species and sixty-five characters used in the cladistic analysis. See character coding explanations in text.

\begin{tabular}{|c|c|c|c|c|c|c|c|}
\hline Taxa & $\begin{array}{l}\text { Characters } \\
0000000001 \\
1234567890 \\
\end{array}$ & $\begin{array}{l}1111111112 \\
1234567890 \\
\end{array}$ & $\begin{array}{l}2222222223 \\
1234567890 \\
\end{array}$ & $\begin{array}{l}3333333334 \\
1234567890 \\
\end{array}$ & $\begin{array}{l}4444444445 \\
1234567890 \\
\end{array}$ & $\begin{array}{l}5555555556 \\
1234567890 \\
\end{array}$ & $\begin{array}{l}66666 \\
12345 \\
\end{array}$ \\
\hline G. inflatus & 0100000001 & 0000000000 & $0000001 ? 00$ & 1000200000 & 0000000100 & 0000000000 & 00001 \\
\hline R. aestivus & 0000000000 & 0000000100 & 0000011000 & 0000003000 & 0000010100 & $0000000 ? 00$ & 00001 \\
\hline R. marginipes & 0000000000 & 0000000100 & 0000010000 & 0000000000 & 0300010000 & $? 000000 ? 00$ & 00001 \\
\hline adanense & 0010011101 & $1010 ? 00001$ & 1111200100 & $2210003 ? 10$ & 0110001000 & 1001200001 & 20221 \\
\hline alatavicum & $000000 ? 10 ?$ & $? 0 ? ? ? 00010$ & 0001200010 & $0010002 ? 11$ & $020 ? ? 01000$ & $? 012011101$ & $20 ? ? ?$ \\
\hline altaicum & 0001011101 & 1000000000 & 0001000000 & 0100004001 & 0300000000 & 1000100111 & 20201 \\
\hline altifrons & 0000011100 & $0000 ? 00100$ & $1000001 ? 00$ & $0000200 ? 00$ & 0000010000 & $0000000 ? 00$ & $000 ? ?$ \\
\hline amphibolum & 0000000100 & $00000 ? 0100$ & 0100001001 & $00 ? 0000000$ & $03000100 ? 0$ & $000 ? 000001$ & 00001 \\
\hline arianae & $000001 ? 101$ & 1000000000 & 0001000000 & 0110003100 & $000 ? ? 01000$ & $? 000000101$ & $2020 ?$ \\
\hline assimile & 0000000100 & 0000001000 & 0000100011 & 0000001000 & 1300000010 & 0000000001 & 20200 \\
\hline atrum & 0001011101 & 1000000000 & 0001000000 & 0100003001 & 0300000000 & 1000100111 & 20201 \\
\hline brucki & $000100 ? 101$ & 1000000000 & 0001000000 & 0300004001 & $0300 ? 00000$ & 1000101111 & $2020 ?$ \\
\hline burmeisteri & 0000000100 & $00 ? 0 ? 01000$ & 0000100011 & 0000001000 & 1300000010 & $? 000000 ? 01$ & $202 ? 0$ \\
\hline cantabricum & 0000000100 & 0000000010 & 0000010000 & $0 ? 00003000$ & 1020000000 & 1010000101 & 20110 \\
\hline circumligatum & 0101001101 & 1111000000 & 0000000010 & 0000005000 & $0000 ? 00001$ & $2000300 ? 01$ & $10 ? 0 ?$ \\
\hline evorense & 0000000100 & $0010 ? 00000$ & 0000010000 & $0300003 ? 00$ & 1000000000 & 0000000101 & 20110 \\
\hline fissiceps & 0010021101 & 1010000001 & 0101000000 & 0010005000 & 0101101000 & 2001300001 & 20201 \\
\hline furvum & $000101 ? 101$ & $1010 ? 00000$ & 0001000000 & $0300004 ? 01$ & 0300000000 & $? 000101111$ & $2020 ?$ \\
\hline fuscum & 0001011101 & 1000000000 & 0001000000 & $0 ? 00004001$ & 0300000000 & 1000100111 & 20201 \\
\hline gianfranceschii & $000010 ? 110$ & $? 0 ? ? ? 00000$ & $0 ? 11211 ? 00$ & $1010113 ? 10$ & $0001 ? 01000$ & 1000000001 & $202 ? ?$ \\
\hline insculptum & $010000 ? 101$ & $? 010100000$ & 0001000100 & 0001003000 & $0000 ? 00 ? 00$ & $2000000 ? 01$ & $2020 ?$ \\
\hline javeti & $000001110 ?$ & $? 00 ? ? 00010$ & 0001200010 & $001 ? 002 ? 11$ & 0200001000 & 0012010101 & 20200 \\
\hline jeannae & $012102 ? 101$ & 1010000000 & 0001000000 & $0400003 ? 00$ & $0000 ? 00000$ & 2000000001 & $2020 ?$ \\
\hline jeannei & $000101120 ?$ & $? 01 ? ? 00000$ & 0001000000 & $0300004 ? 01$ & 0300000000 & $? 00010 ? 101$ & $1020 ?$ \\
\hline julieni & 0000011101 & $0000 ? 00100$ & $1000001 ? 00$ & $000 ? 200 ? 00$ & 0000010000 & $? 01 ? 300 ? 00$ & $000 ? ?$ \\
\hline leuthneri & 0010011101 & 1010100001 & 1111200100 & 0010005000 & 0101101000 & 1001200001 & 20221 \\
\hline litigiosum & 0100001101 & 0010000000 & 0001000100 & 0001003000 & 0000000100 & 2000000001 & 20201 \\
\hline lusitanicum & 1000000100 & 0000010010 & 0000011001 & 0000003000 & $? 000000010$ & 0110000101 & 20110 \\
\hline maevae & $000001 ? 101$ & 1000100000 & 0001001000 & $041000300 ?$ & $0000 ? 01000$ & 1002010101 & $2020 ?$ \\
\hline majale & 0000000100 & 0000001010 & 0000101011 & 0000001000 & 1300000010 & 0000000001 & 20200 \\
\hline maniense & $000110 ? 101$ & 1010100000 & 0111200000 & $2010115 ? 10$ & $0101 ? 01000$ & 1000000001 & $2020 ?$ \\
\hline melillanum & 0000000100 & $0000 ? 00100$ & $1000001 ? 00$ & $000 ? 200 ? 00$ & 0000010000 & $0000000 ? 00$ & $010 ? ?$ \\
\hline menori & $010 ? 01 ? 10 ?$ & $? 01 ? ? 00000$ & 0001000000 & $0000005 ? 00$ & $0000 ? 00000$ & $? 000000001$ & $2020 ?$ \\
\hline mussardi & $000001 ? 101$ & 0000000000 & 0001000000 & 0100004000 & $0000 ? 00000$ & 2000000001 & $2020 ?$ \\
\hline naceyroi & $010101 ? 101$ & $0 ? 10000000$ & 0001000000 & 0000005000 & $0000 ? 00000$ & $2000000 ? 01$ & $2020 ?$ \\
\hline nigripenne & $001001 ? 101$ & 1010100001 & 1111200100 & 2210003000 & $0010 ? 01000$ & 1001200001 & $2022 ?$ \\
\hline nigrum & 0000001110 & 0000100000 & $0111211 ? 00$ & 0010113001 & $? 000001000$ & 1000000001 & 20200 \\
\hline obscurum & 0001011101 & 0000000000 & 0001000000 & 0100004000 & 0300000000 & 1000000001 & $202 ? 0$ \\
\hline occidentale & 0000001101 & 0010000000 & 0001000100 & 0100003000 & 0000000000 & 2000000001 & 20201 \\
\hline ochraceum & $00001 ? 1101$ & 1000100010 & 0001200010 & 2010002011 & 0000001000 & 1012011101 & 20200 \\
\hline peropacum & $000000 ? 101$ & $000 ? 000000$ & 0001000000 & 0001003000 & $0300 ? 01101$ & $? 001200101$ & $2020 ?$ \\
\hline pini & 0000101101 & 0000100000 & $0111211 ? 00$ & $1010113 ? 11$ & $000200 ? 000$ & 0000000001 & 20200 \\
\hline pseudomajale & 0000000100 & 0000001010 & 0000101011 & 0000001000 & 1300000010 & 0000000001 & $2020 ?$ \\
\hline pygiale & 0000101110 & 0000100000 & $0111210 ? 00$ & 1010113011 & 0000001000 & $? 000000001$ & 20200 \\
\hline roris & 1000000100 & 0000010000 & 0000011001 & 0000003000 & $? 010000110$ & 0110001101 & $2011 ?$ \\
\hline ruficorne & 0000000100 & 0000000000 & 0000000010 & 0300001000 & 1300000000 & 1000000001 & 20200 \\
\hline safiense & $010100 ? 101$ & 0010000000 & 0001000000 & $0001003 ? 00$ & $0000 ? 00100$ & 2000000001 & $2022 ?$ \\
\hline sainzii & 0000000100 & 0000000010 & 0000011000 & 0100003000 & 1020000000 & 0110000101 & 20110 \\
\hline scutellare & $000000110 ?$ & $? 0 ? 0 ? 00100$ & $1000001 ? 00$ & $000 ? 200 ? 00$ & 0000010000 & $? 000000100$ & $0 ? 0 ? 1$ \\
\hline seidlitzi & 0000000100 & 0000010010 & 0000011001 & 0000003000 & 1000000010 & 0110000101 & 20110 \\
\hline solstitiale & $00001 ? 1101$ & 1000100010 & $0 ? 01200010$ & 2010002011 & 0202001000 & 0012011101 & 20200 \\
\hline spartanum & 0000021101 & 1010000000 & 0101000100 & 0010003100 & $0000 ? 01000$ & 1000000101 & $2020 ?$ \\
\hline subcristatum & $000000010 ?$ & $? 000 ? 00100$ & $1000001 ? 00$ & $000 ? 200 ? 00$ & 0000010000 & $00 ? ? 000 ? 00$ & $010 ? ?$ \\
\hline subparallelum & 0000000100 & 0000000100 & $1000001 ? 00$ & $0000200 ? 00$ & 0000010000 & $? 0 ? 0000000$ & 01001 \\
\hline theryi & $002001 ? 101$ & 1010000000 & 0001000000 & 0401003000 & $0000 ? 00000$ & 2000000001 & $2020 ?$ \\
\hline vernale & 0010011101 & 1000100001 & $0 ? 01000000$ & $001000500 ?$ & 0101101000 & 1000200001 & 20201 \\
\hline verticale & $000001 ? 101$ & 1000100000 & 0001001000 & 0010003000 & $0000 ? 01000$ & $? 002010101$ & $2020 ?$ \\
\hline vitalei & 0000101110 & $? 00 ? ? 00000$ & $0111211 ? 00$ & $1210113 ? 10$ & $0001 ? 01000$ & $? 000000001$ & $2020 ?$ \\
\hline vivesi & $000010 ? 110$ & $? 0 ? ? ? 00000$ & $0011211 ? 00$ & $12 ? 0113 ? 11$ & $0000 ? 01000$ & $? 000000001$ & $2020 ?$ \\
\hline volgense & $000001 ? 101$ & 1000100000 & 0001000010 & $001000200 ?$ & $0200 ? 01000$ & 1002010101 & $2020 ?$ \\
\hline vulpecula & $010100 ? 101$ & 0111000000 & 0000000000 & 0000002000 & 0200010001 & $? 00030000 ?$ & $00 ? 0 ?$ \\
\hline
\end{tabular}




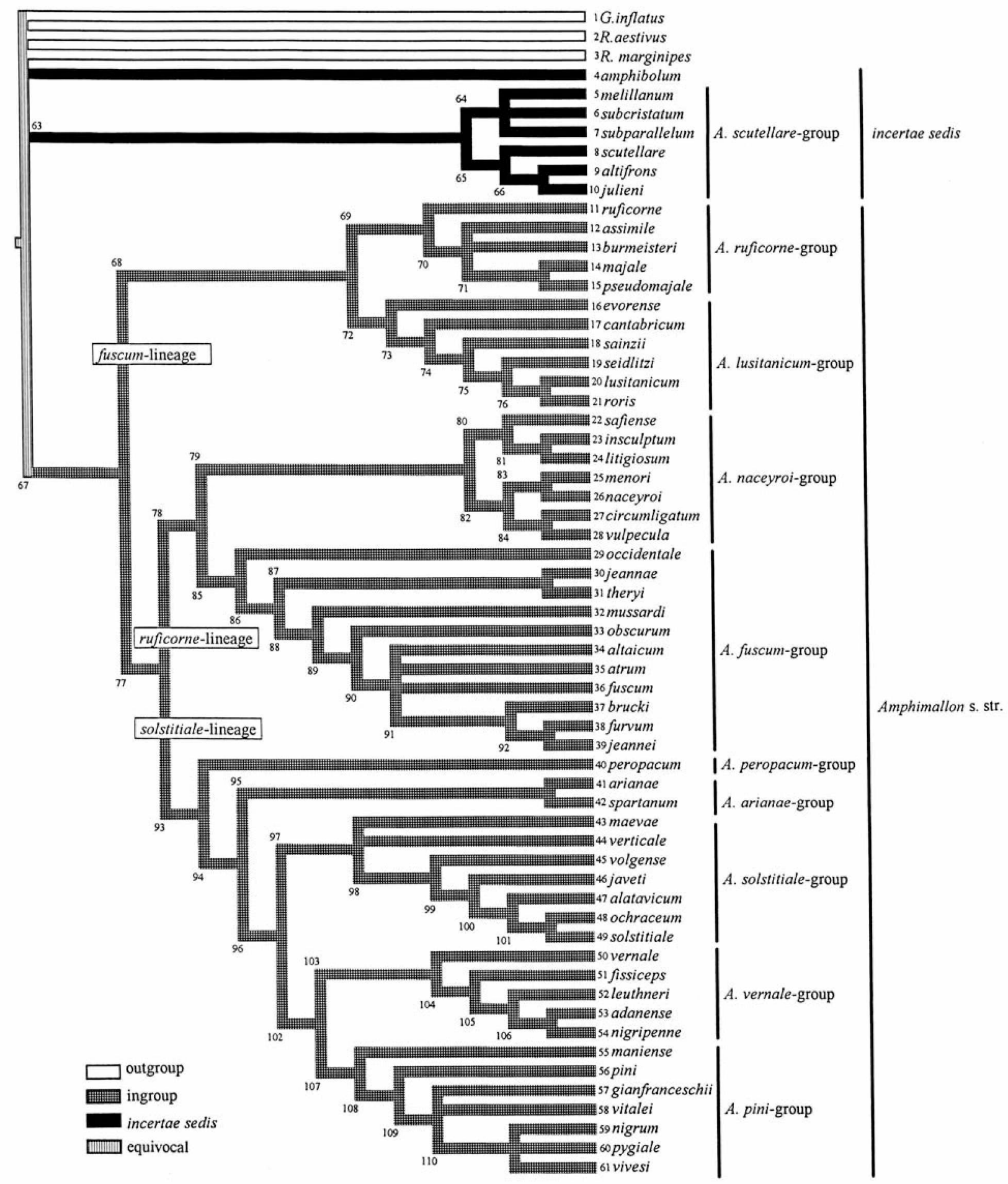

Fig. 6. Strict consensus of seventy-two equally parsimonious trees for Amphimallon based on cladistic analysis of sixty-five morphological characters. Tree length $=223$ steps, consistency index $=0.4$, retention index $=0.8$. Numbers refer to branch points.

the "pini-group" introduced by Reitter (1902) and redefined by Baraud $(1967,1992)$. A seventh species from Greece, A. maniense sp. n., is added, which branches off in basal position.

The monophyly of this group is supported by six synapomorphies: odd elytral interstriae strongly elevated (character 35), but the fifth not so strongly in $A$. maniense; odd elytral interstriae with fine transversal ridges (character 36) which generally conceal the punctation (in $A$. maniense, these ridges are sparsely distributed and do not conceal the punctation); frons of male without clear carina (character 6); disc of abdominal sterna, except the last one, darkened (character 39); characteristic colour pattern of head (character 5) (except in A. nigrum which is a totally black species), with the clypeus yellowbrown and the cephalic capsule brown or black (in $A$. 


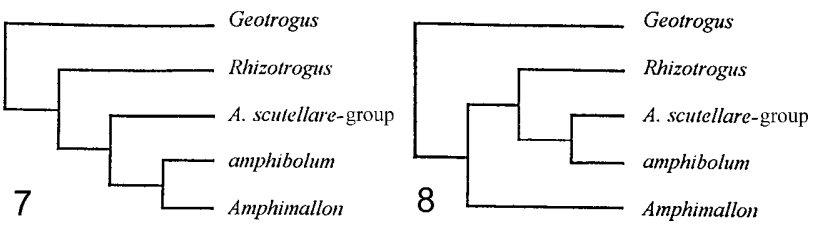

Figs 7-8. Phylogenetic relationship pattern between Amphimallon, Rhizotrogus, A. scutellare-group and A. amphibolum. 7 - monophyly of Amphimallon + A. scutellare-group + amphibolum; 8 - monophyly of Rhizotrogus + scutellare-group + amphibolum.

maniense, this colouration is not so contrasted due to the cephalic capsule feebly darkened); pronotum with a median furrow present at least in the posterior part (character 23).

The clade $A$. gianfranceschii-nigrum-pini-pygiale-vitalei-vivesi is supported by four synapomorphies: pronotum with a very fine punctation without setae (character 26) in addition to the fine, dense and regular main punctation (character 25); second antennal club segment with only its dorsal margin smooth, the ventral margin with area of sensilla (character 11); disc of pronotum black or dark brown, presenting an obvious contrast with the yellowish sides, except in A. nigrum (character 31) (in A. maniense, the pronotal disc has only confused darkened flecks).

The clade $A$. gianfranceschii-nigrum-pygiale-vitalei-vivesi is supported by the shape of the antennal club which is strongly elongated and curved before apex (character 9). The sensillar area of inner side of first antennal club segment is prolonged and developed on the outer side basis (10).

\section{The $A$. vernale-group}

This group is composed of four species from Balkan and Asia Minor, A. adanense sp. n., A. leuthneri Brenske, 1902, A. nigripenne Reitter, 1902, A. vernale (Brullé, 1832), and one species, $A$. fissiceps Fairmaire, 1860, from Morocco.

Amphimallon vernale (Brullé, 1832) is usually considered a synonym of $A$. caucasicum (Gyllenhal, 1817) (Reitter, 1902; Medvedev, 1951; Baraud, 1992). The comparison of the types of Melolontha caucasica Gyllenhal, 1817, preserved in Stockholm (NHRS), and of Rhizotrogus vernalis Brullé, 1832, preserved in Paris (MNHN), shows that the synonymy between both names is false. The type of Melolontha caucasica does not correspond to the species named $A$. caucasicum by the authors. In addition, this taxon does not belong to Amphimallon, but to Miltotrogus Reitter, 1902 by the lack of the basal pronotal margin and by the shape of the aedeagus.

Therefore, a new combination is established: Miltotrogus caucasicus (Gyllenhal, 1817) comb. $\mathrm{n}$.

The type of $R$. vernale Brullé corresponds to the name A. caucasicum of the authors. Thus, Amphimallon vernale (Brullé, 1832) $=$ A . caucasicum sensu auctorum nec Miltotrogus caucasicus (Gyllenhal, 1817).

Amphimallon leuthneri Brenske, 1902 was originally described as a variety of A. caucasicum (Gyllenhal,
1817). It was raised to the rank of species by Medvedev (1951). This conclusion is confirmed by sister-group relationship between this taxon and $A$. adanense $+A$. nigripenne.

This group is defined by four synapomorphies: clypeus strongly raised in the corners and apparently bilobate (character 3), but this character is not constant in $A$. vernale; lateral edges of pronotum clearly raised in anterior part (character 20); tridentate external edge of female protibiae strongly enlarged (character 45); apex of parameres, in lateral view, with a curved tooth, salient towards ventral side of parameres (character 55), except in $A$. fissiceps which presents a blunted apex.

The monophyly of the clade A. fissiceps-adanenseleuthneri-nigripenne is supported by two synapomorphies: apex of parameres in lateral view regularly curved (character 54); two paramedian lines of short and dense setae on dorsal side of labium lacking (character 13).

The monophyly of the clade $A$. adanense-leuthnerinigripenne is strongly supported by five synapomorphies: lateral edges of pronotum not crenellated in front part (character 21), due to the lack of punctation which usually bears hair-like setae on the sides of pronotum; disc of pronotum with short and inclined setae (character 28); punctation of pronotum regular, not very dense, fine (character 25) but quite stronger in $A$. adanense; disc of pronotum with a median furrow in posterior part (character 23); endophallus with extremely reduced ventral median area of spicules (character 63).

Sister-group relationship between $A$. pini-group and $A$. vernale-group is supported by three synapomorphies: a wide ventro-median sub-apical non-sclerotized area of paramere (character 58); basal margin of pronotum enlarged (character 22, this character is not constant in all the species of this group and can be occasionally present in species which do not belong to it); external edge of protibiae tridentate, the median tooth close to the basal (character 44). A reversal of this character is observed in the clades $A$. adanense-nigripenne and $A$. nigrumpygiale-vivesi. In $A$. pini, the male protibia is unidentate.

The $A$. solstitiale-group

This group is composed of seven species: A. alatavicum Medvedev, 1951, A. javeti Stierlin, 1864, A. maevae Montreuil, 1999, A. ochraceum (Knoch, 1801), A. solstitiale (L., 1758), A. verticale (Burmeister, 1855) and $A$. volgense (Fischer, 1823).

Amphimallon javeti Stierlin is usually considered the Sicilian subspecies of $A$. solstitiale (L.). Its colour pattern and the lack of sub-apical spicules on the dorsal side of parameres, which are present in $A$. solstitiale, $A$. ochraceum and $A$. alatavicum, allow us to raise it to the species rank.

The monophyly of this group is supported by two synapomorphies: apex of parameres in lateral view straight and elongated (character 54); apex of parameres in dorsal view with an internal concavity (character 56 ).

The phylogenetic relationships of this group are not completely resolved, but the species volgense, javeti, 

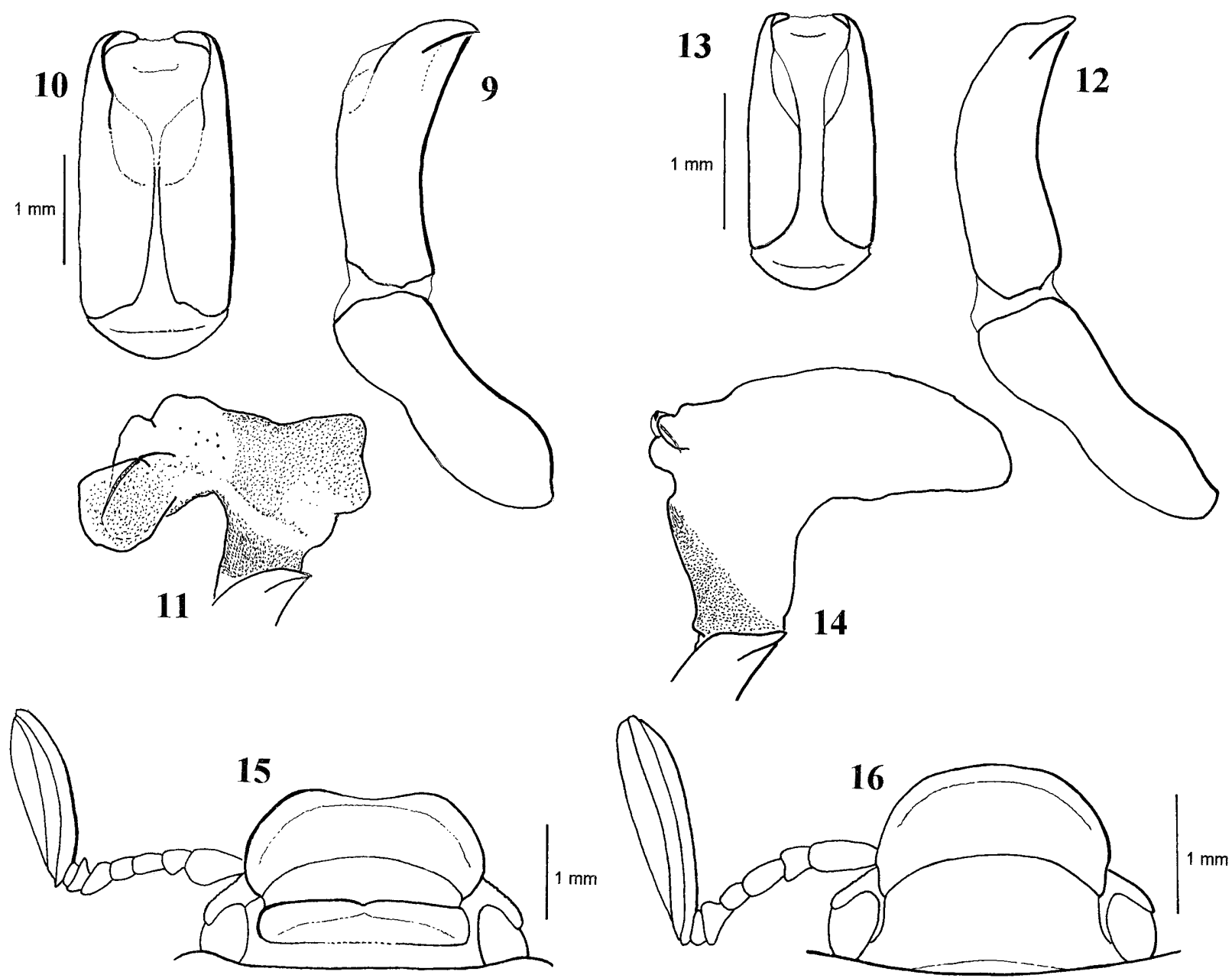

Figs 9-16. 9-11, 15: Amphimallon adanense sp. n. 9 - aedeagus (lateral view); 10 - parameres (dorsal view); 11 - endophallus (lateral view); 15 - head (dorsal view, setae and punctation omitted). 12-14, 16: A. safiense sp. $\mathrm{n} .12$ - aedeagus (lateral view); 13 parameres (dorsal view); 14 - endophallus (lateral view); 16 - head (dorsal view, setae and punctation omitted).

altaicum, ochraceum and solstitiale form a monophyletic group which is supported by three synapomorphies: sides of pronotal disc with irregular inclined short setae which often form a conspicuous white fleck (character 29); elytral disc with long sparse setae (character 37), shorter in volgense, lacking in posterior part in A. ochraceum; pygidium bearing very long and raised setae (character 42) which are generally absent in A. ochraceum.

The clade $A$. javeti-altaicum-ochraceum-solstitiale is defined by four synapomorphies: posterior part of lateral edge of pronotum feebly sinuate (character 19); main punctation of pronotum fine, dense and quite regular (character 25); abdominal sterna, except the last one, yellow-brown with darkened disc (character 39); parameres in lateral view thick (character 53).

The clade $A$. altaicum-ochraceum-solstitiale is supported by a single synapomorphy: dorsal side of parameres with a subapical area of spicules (character 57).

The clade $A$. ochraceum-solstitiale is supported by two synapomorphies: head clearly bicoloured, clypeus yellowish brown, brown or black cephalic capsule (character 5) (convergence with the $A$. pini-group); disc of pronotum with confused dark maculae (character 31 ).
Sister-group relationship between this group and $A$. pini-group $+A$. vernale-group is supported by a single synapomorphy: punctation of the outer side of mandible fine and superficial, hardly perceptible (character 15), but a reversal is observed in $A$. fissiceps.

The $A$. arianae-group

This group includes two species from Greece and Aegean Sea islands: A. arianae (Fairmaire, 1879) sensu Montreuil (1999) and A. spartanum (Brenske, 1884).

The monophyly of this group is supported by a single synapomorphy: posterior margin of first visible sternum medially V-shaped (character 38).

Sister-group relationship between this group and $A$. pini-group $+A$. vernale-group $+A$. solstitale-group is supported by three synapomorphies: metasternum with robust spinose setae in addition to the hair-like setae (character 33); second antennal club segment with ventral and dorsal margin smooth, both without sensillar area (character 11); frons of male with a strong transverse carina which reaches the sides of the head (character 6). However, reversals for this last two characters are observed in the $A$. pini-group. 


\section{The $A$. peropacum-group}

This group includes a single species from Portugal, $A$. peropacum Reitter, 1911, which is one of the most recognizable species of Amphimallon. In addition to the characters treated in this phylogenetic analysis, this species is characterized by many other autapomorphies, and in particular the shape of its parameres, the raspy punctation of its pronotum and the rough surface of its tegument.

Sister-group relationship between this species and other groups composing the $A$. solstitiale-lineage is supported by two synapomorphies: inner spur of protibiae clearly inserted between median and apical teeth (character 47); ventro-median sub-apical non sclerotized area of paramere narrow (character 58), but a reversal is observed in the $A$. pini-group $+A$. vernale-group.

\section{The $A$. fuscum-lineage}

This lineage is composed of two monophyletic groups and presents sister-group relationships with the $A$. solstitiale-lineage.

\section{The A. fuscum-group}

This group is composed of eleven species from North Africa, Europe and Central Asia: A. jeannae sp. n., $A$. mussardi (Antoine, 1959), A. obscurum Reiche, 1864, A. occidentale Petrovitz, 1964, A. theryi Peyerimhoff, 1949 and the monophyletic group composed of A. altaicum (Mannerheim, 1825), A. atrum (Herbst, 1790), A. brucki (Fairmaire, 1879), A. furvum (Germar, 1817), A. fuscum (Scopoli, 1786) and A. jeannei (Baraud, 1971).

Amphimallon furvum (Germar, 1817) was considered a simple variety, and recently (Miksic, 1970) a subspecies of Amphimallon fuscum (Scopoli, 1786). Its particular elytral colour pattern and the presence of spicules on the dorsal side of parameres allow us to raise this taxon to the species rank.

Amphimallon jeannei (Baraud, 1971) comb. n. was originally described in Monotropus Erichson, 1848 on the basis of its 8-segmented antennae. In fact, this species finds a place in the A. fuscum-group of Amphimallon.

This group is defined by a single synapomorphy: pronotum and elytra have a distinctive tint (character 32 ). The pronotum is dark reddish brown and elytra reddish brown, but the monophyletic clade $A$. jeannae-theryi presents pale reddish brown elytra (convergence with maevae) and the clade $A$. brucki-furvum-jeannei presents yellowish-brown elytra (convergence with $A$. ruficorne, $A$. evorense and $A$. arianae).

In addition to its particular colour pattern, the monophyletic group A. jeannae-theryi is defined by two synapomorphies: edge of clypeus strongly lifted all around, the clypeus deeply concave (character 3 ); second antennal club segment with ventral and dorsal margin smooth, both without sensillar area (character 11).

The monophyly of the clade $A$. altaicum-atrum-bruckifurvum-fuscum-jeannei-obscurum-mussardi is supported by two synapomorphies: elytral disc with quite long and inclined, regularly distributed setae (character 37); dorsal side of labium with two paramedian lines of short and dense setae (character 13).
The monophyly of the clade A. altaicum-atrum-bruckifurvum-fuscum-jeannei-obscurum is supported by three synapomorphies: clypeus with long and raised hair-like setae (character 4); pygidium with short, but clearly perceptible, raised setae (character 42); crypts in male mesenteron present, but feebly developed (character 51).

The monophyly of the clade A. altaicum-atrum-bruckifurvum-fuscum-jeannei is strongly supported by four synapomorphies: apex of parameres, in lateral view, clearly inflated (character 55); ventro-median sub-apical non sclerotized area of parameres narrow (character 58) and irregularly limited laterally (character 59), but reversed in jeannei; second antennal club segment with ventral and dorsal margin smooth, both without sensillar area (character 11) (convergence with $A$. jeannae-theryi, $A$. circumligatum and part of $A$. solstitiale-lineage).

The monophyly of the clade $A$. brucki-furvum-jeannei is supported by a single synapomorphy in addition to the colour pattern: dorsal side of parameres with a subapical area of spicules (character 57) (convergence with a part of A. solstitiale-group), however, only traces of spicules are observed in A. jeannei.

\section{The $A$. naceyroi-group}

This group is composed of seven species from Morocco and the Iberian Peninsula in two monophyletic groups: $A$. safiense sp. n., A. insculptum Brenske, 1889 and $A$. litigiosum Fairmaire, 1860, in the first group, $A$. circumligatum Peyerimhoff, 1949, A. menori Baguena, 1955, A. naceyroi Mulsant, 1859 and $A$. vulpecula Peyerimhoff, 1931 in the second group.

Type comparison and the study of many specimens allows to establish the new synonymy between $A$. litigiosum Fairmaire, 1860 and A. galleti Baraud, 1970.

This group is supported by a single synapomorphy: clypeus enlarged (character 2 ).

The clade A. safiense-litigiosum-insculptum is defined by the superior spur of metatibiae enlarged before apex (character 48 ) and by the elytra clearly laterally enlarged in the front part (character 34).

The clade $A$. menori-naceyroi-circumligatum-vulpecula is supported by the elytral disc clothed with long and inclined, irregularly distributed setae (character 37 ).

The clade $A$. menori-naceyroi is supported by the frons of the male with a strong transverse carina (character 6).

The monophyly of the clade $A$. circumligatumvulpecula is strongly supported by five synapomorphies: eyes of males strongly enlarged (character 12); postmentum absent (character 14); tegument of pronotum smooth (character 24); ventral edge of claw without a basal tooth (character 50); apex of parameres, in lateral view, blunted (character 55).

Sister-group relationship between A. fuscum-group and $A$. naceyroi-group is supported by two synapomorphies: absence of the two paramedian lines of short and dense setae on the dorsal side of labium (character 13), with a reversal in a part of $A$. fuscum-group; endosymbiotic crypts in mesenteron absent in the male (character 51), also with a reversal in a part of $A$. fuscum-group. 

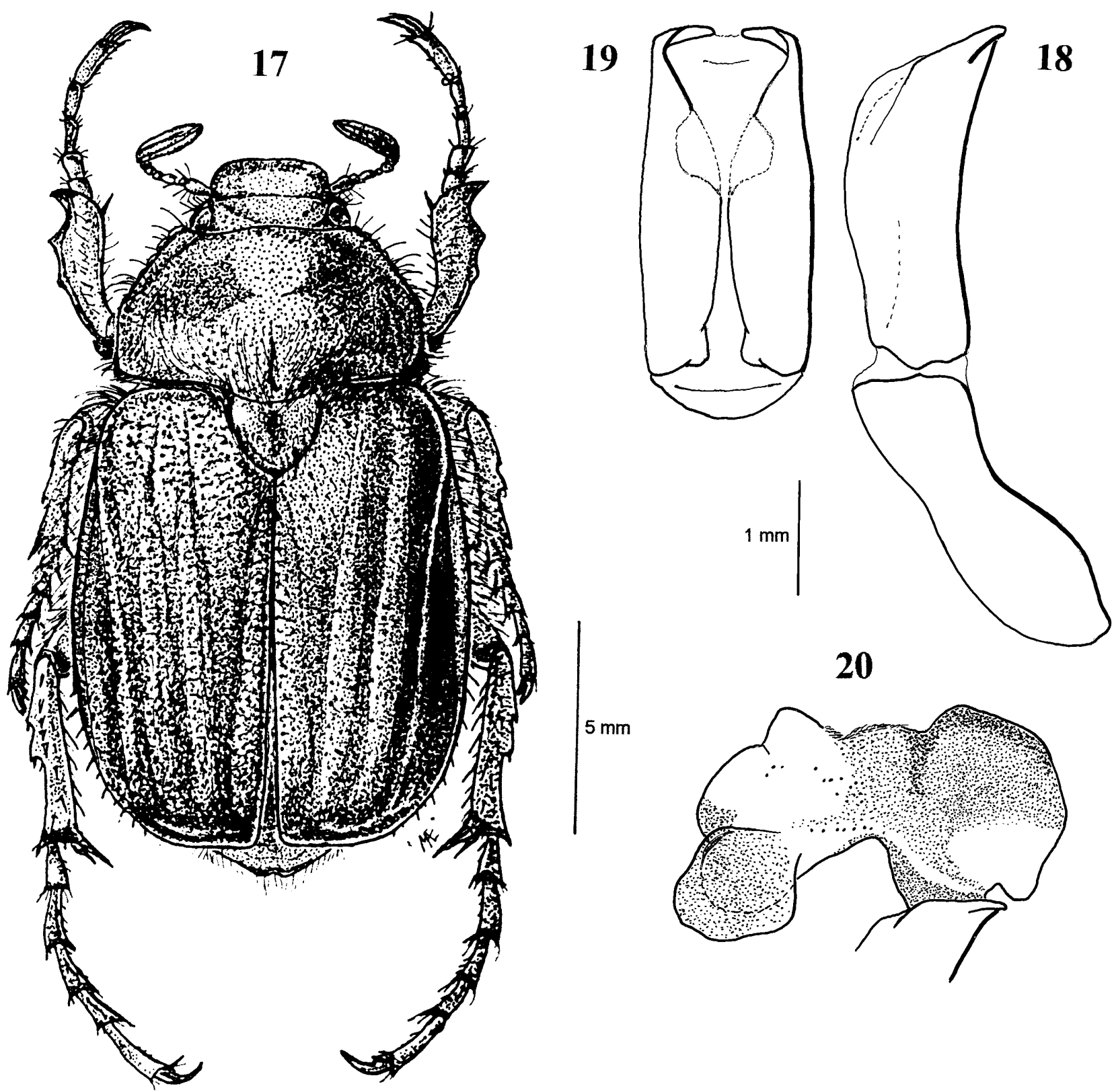

20

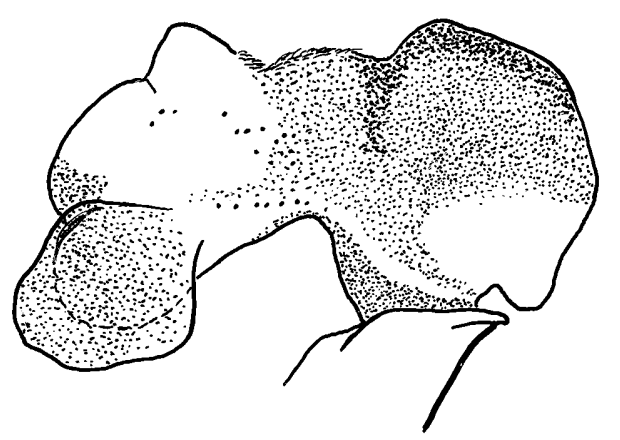

Figs 17-20. Amphimallon maniense sp. n. 17 - habitus; 18 - aedeagus (lateral view); 19 - parameres (dorsal view); 20 - endophallus (lateral view).

Sister-group relationship between the $A$. fuscum-lineage and the $A$. solstitiale-lineage is supported by two synapomorphies: frons of the female with a strong transverse carina (character 7); tegument of pronotum microreticulated (character 24), with a reversal in $A$. circumligatusvulpecula ( $A$. naceyroi-group) and $A$. maniense ( $A$. pini-group).

\section{The A. ruficorne-lineage}

This lineage is composed of two monophyletic groups and presents sister-group relationships with the two previous lineages.

The $A$. ruficorne-group

This group includes five species from western and central Europe: A. assimile (Herbst, 1790), A. burmeisteri Brenske, 1886, A. majale (Razoumowsky, 1789), A. pseu- domajale Sabatinelli, 1976 and A. ruficorne (F., 1775) in the basal position.

The monophyly of this group is supported by three synapomorphies: pygidium with short but clearly perceptible regularly distributed raised setae (character 42), shorter in A. ruficorne; elytral disc with short regularly distributed raised setae (character 37); pronotal disc with short setae from fine punctuation (29).

The monophyly of the clade $A$. assimile-burmeisterimajale-pseudomajale is supported by four synapomorphies: pronotum with a very fine and dense punctation, bearing short inclined setae (character 25) which give the pronotum a silky aspect; pronotum transverse (character 17); narrow prosternal basisternum with a transversal furrow (character 30); ventral edge of second tarsomere of protarsus clearly and strongly dentate (character 49). 

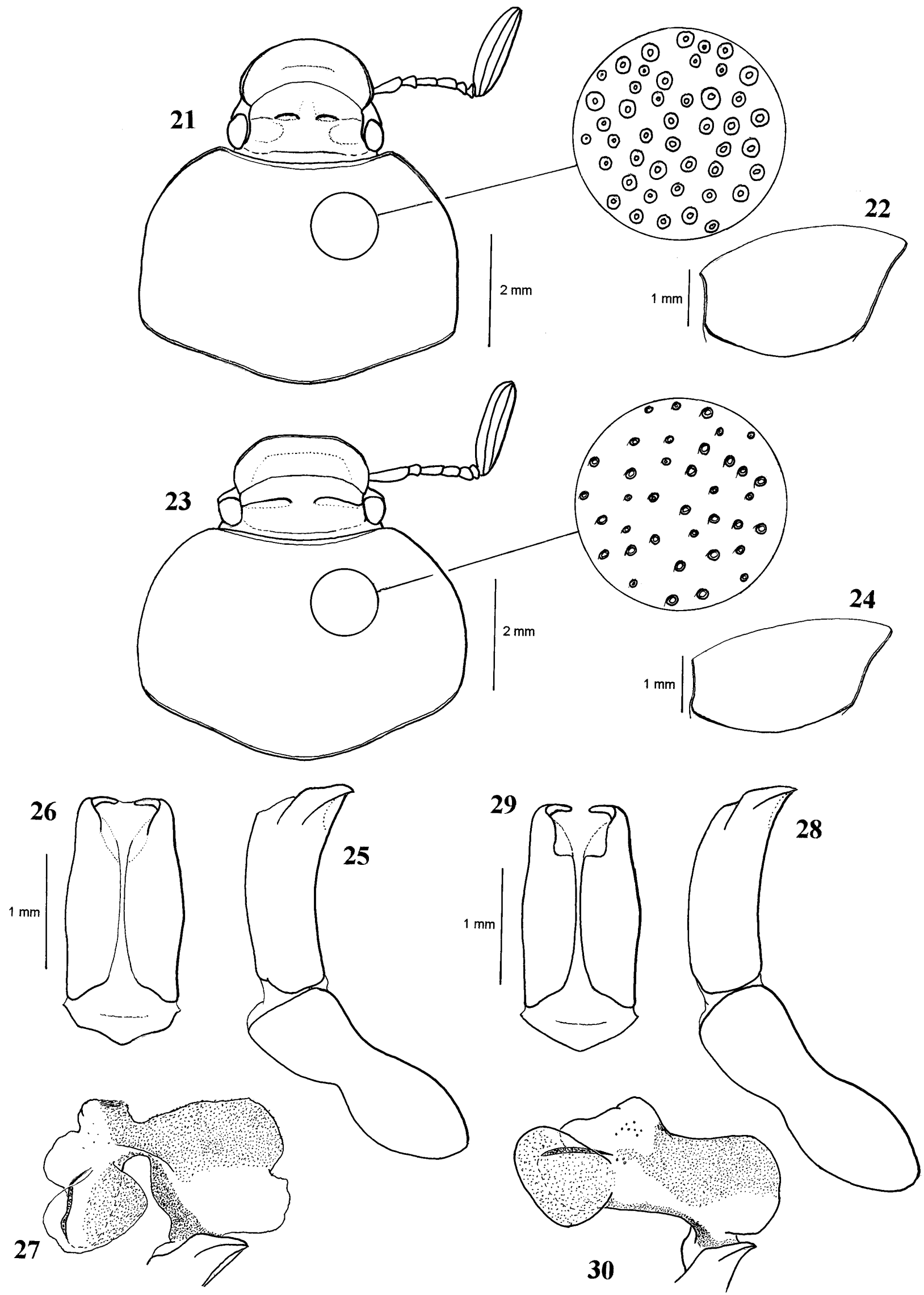

Figs 21-30. 21, 22, 25-27: Amphimallon theryi Peyerimhoff. 21 - pronotum and head (dorsal view; setae and punctation omitted) with detail of pronotal punctation; 22 - shape of pronotum (lateral view); 25 - aedeagus (lateral view); 26 - parameres (dorsal view); 27 - endophallus (lateral view). 23, 24, 28-30: A. jeannae sp. n. 23 - pronotum and head (dorsal view; setae and punctation omitted) with detail of pronotal punctation; 24 - shape of pronotum (lateral view); 28 - aedeagus (lateral view);29 - parameres (dorsal view); 30 - endophallus (lateral view). 
The monophyly of the clade A. majale-pseudomajale is supported by the absence of main punctation of pronotal disc (character 27 ). The pronotal disc presents only a very fine and dense punctation bearing short inclined setae. Hair-like setae are absent from the disc because of the lack of main punctation.

\section{The A. lusitanicum-group}

This group is composed of six species from the Iberian Peninsula: A. cantabricum Heyden, 1870, A. lusitanicum (Gyllenhal, 1817), A. roris Baraud, 1981, A. sainzil (Graëlls, 1858), A. seidlitzi Brenske, 1891 and $A$. evorense Reitter, 1913 in basal position. It corresponds largely to the "A. lusitanicus-group" introduced by Reitter (1902) and redefined by Baraud (1981).

The description of Amphimallon trisinuatum Reitter, 1902 was based on a single female from Portugal, Sierra da Estrella. This species has never been recaptured since its description. The authors who have studied the Iberian fauna (Báguena, 1959, 1967; Baraud, 1977b; Martin Piera, 1985) did not know this species, which was even called "enigmatic" by Baraud (1992). I have studied the type of this name which is preserved in Budapest (HNHM). The lack of setae at the basis of pronotum, considered by Reitter as a specific character, is due to the poor condition of the specimen. In fact, this specimen is barely different from Amphimallon seidlitzi Brenske, 1891, a species common in Sierra da Estrella, by the shape of the clypeus, which is trisinuate. I have also met this particular clypeal shape in a specimen of $A m p h i$ mallon majale (Razoumowsky, 1789) from Montpellier, France (MNHN, A. Mackanga leg). Other specimens, like the type-specimen of Amphimallon litigiosum Fairmaire, 1860 (MNHN), or a specimen of Amphimallon solstitiale pictum Kraatz, 1902 from Greece (MNHN), present only a single lateral sinuosity which gives the clypeus an asymmetrical shape. These specimens may be teratologic cases (e.g., due to defective maturation).

Therefore Amphimallon seidlitzi Brenske, $1891=$ Amphimallon trisinuatum Reitter, 1902 syn. n.

The monophyly of this group is supported by four synapomorphies: pronotum with a very fine superficial punctation without setae between main punctation (character 26) (convergence with a part of $A$. pini-group); narrow ventro-median sub-apical non-sclerotized area of parameres (character 58); dorsal basis of endophallus with dense area of spicules which does not expand basally on the sides (character 63); ventro-median spiculate area of endophallus clearly delimited, its anterior part M-shaped (character 64).

The monophyly of the clade $A$. cantabricum-sainziiseidlitzi-lusitanicum-roris is supported by two synapomorphies: posterior part of lateral edge of pronotum sinuate (character 19) (convergence with a part of $A$. ruficorne-group and $A$. solstitiale-group), reversed in roris; parameres, in lateral view, thick (character 53) (convergence with a part of $A$. solstitiale-group).

The clade $A$. sainzi-seidlitzi-lusitanicum-roris is defined by two synapomorphies: hair-like setae of pronotal disc lacking at least from the front part and on the sides (character 27); parameres in dorsal view clearly inflated (character 52).

The clade $A$. seidlitzi-lusitanicum-roris is supported by three synapomorphies: apical segment of labial palpas strongly inflated (character 16); narrow prosternal basisternum, with a transversal furrow (character 30) (convergence with a part of the $A$. ruficorne-group); ventral edge of second tarsomere of protarsus clearly and strongly dentate (character 49) (convergence with a part of $A$. ruficorne-group).

The clade $A$. lusitanicum-roris is defined by the strongly enlarged head (character 1 ).

Sister-group relationship between $A$. lusitanicum-group and $A$. ruficorne-group is supported by a single synapomorphy: pygidium with a regular, dense and strong punctation (character 41).

\section{DESCRIPTIONS OF NEW SPECIES}

\section{Amphimallon adanense sp. $\mathbf{n}$.}

Description. Length: 13-15 mm. Reddish brown head, antennae, mouth-parts and legs yellow-brown. Disc of pronotum pale reddish brown, with a median line and symmetrical flecks dark reddish brown, sides yellowbrown. Dark reddish brown elytra. Last sternum yellowbrown, disc of other sterna pale reddish brown. Yellowbrown pygidium, with a reddish brown median fleck.

Head (Fig. 15). Frons hairy, armed with a strongly elevated transverse carina, interrupted in the middle, stronger in the female. Edge of clypeus strongly lifted and sinuated in the middle. Antennae 9-segmented, club shorter than the other segments together.

Pronotum. Sides rounded, in front part, with a thin, uncrenellate and lifted edge. Posterior part of disc with a feeble, but clearly perceptible, median furrow. Surface of tegument microreticulated. Punctation dense, punctures spaced by $1-1.5$ times their diameter. Clothed with short, inclined setae, hardly perceptible. Basal margin enlarged, but thinner scutellum.

Elytra. Odd interstriae elevated, 9th very feebly. Punctation strong and dense on even interstriae, odd interstriae more sparsely punctured. Setae short, inclined, but easily visible.

Pygidium. Punctation dense, superficial. Setae very short, inclined, hardly visible.

Legs. Protibiae tridentated, teeth strongly enlarged in female.

Aedeagus (Figs 9-10). Parameres regularly curved before apex in lateral view. Apex with a small curved tooth toward ventral side. Endophallus as in Fig. 11.

Type material. Holotype: $1 \delta$, Turkey, Adana (MNHN). Paratypes: $8 \delta$ and $1 \%$, same data (MNHN).

Etymology. Species named after its occurrence in Adana.

Remarks. Amphimallon adanense sp. $\mathbf{n}$. belongs to a natural group which includes also two species described from the same locality in Turkey, Adana: Amphimallon nigripenne Reitter, 1902 and Amphimallon leuthneri Reitter, 1902. Amphimallon adanense sp. $\mathrm{n}$. differs from both species by the stronger punctation of pronotum and elytra, 

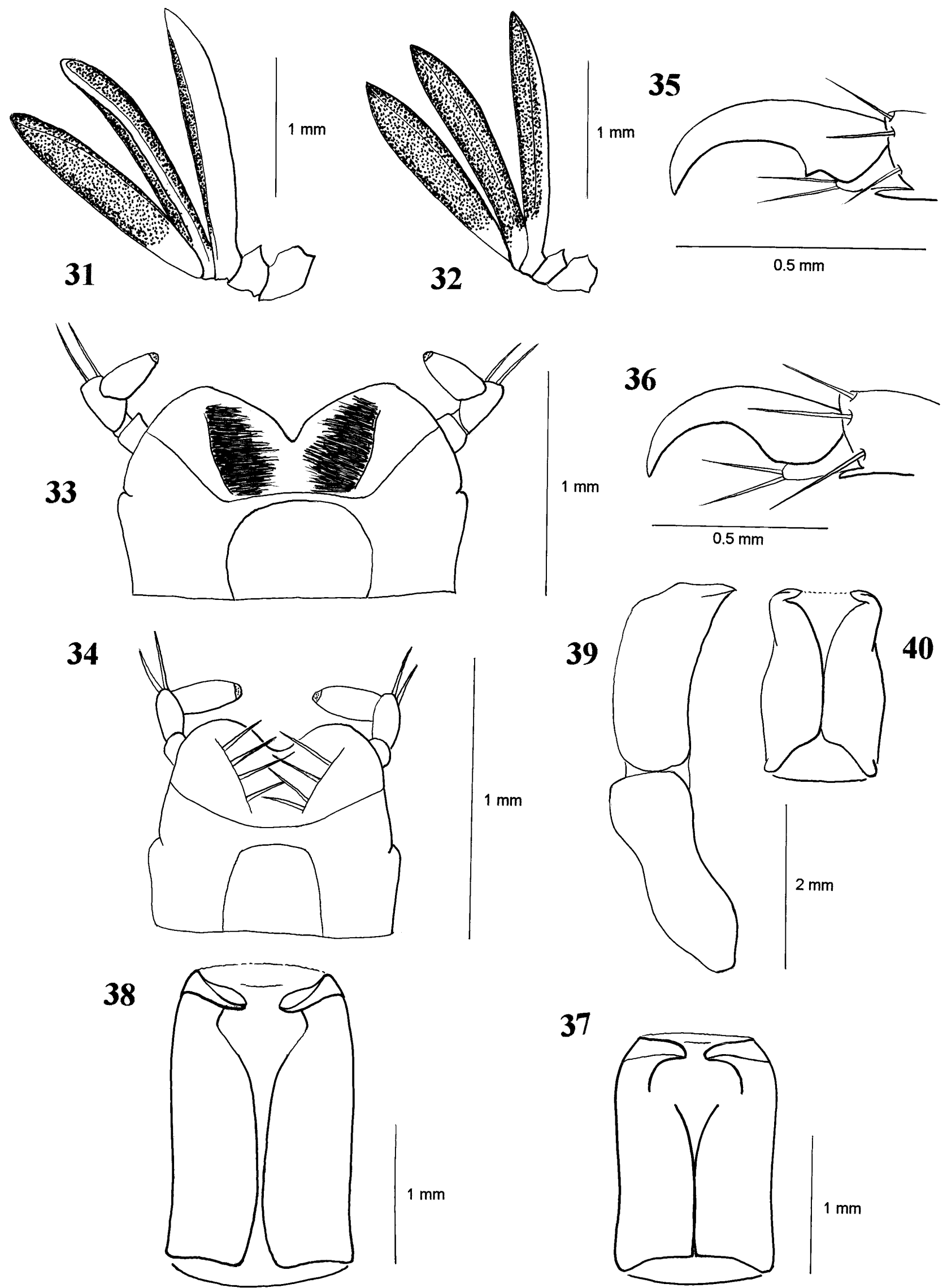

Figs 31-40. Morphology of Amphimallon. 31, 32: Antennal club (ventral view, setae omitted). 31 - A. leuthneri; $32-$ A. seidlitzi. 33, 34: Labium (dorsal view). 33 - A. pini; $34-$ A. leuthneri. 35, 36: Claw (lateral view). $35-A$. pygiale; $36-A$. peropacum. 37 , 38: Parameres (ventral view). 37 - A. ruficorne; 38 - A. maevae. 39, 40: Aedeagus of A. seidlitzi. 39 - lateral view; 40 - dorsal view. 
41

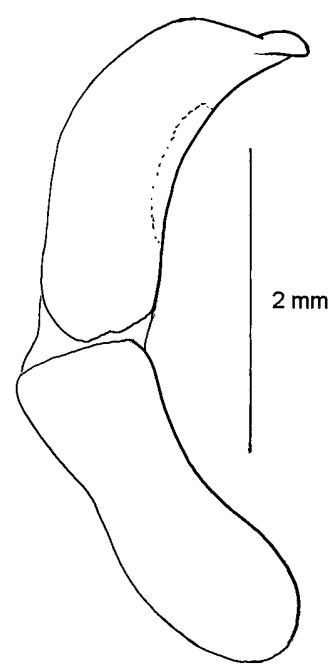

43

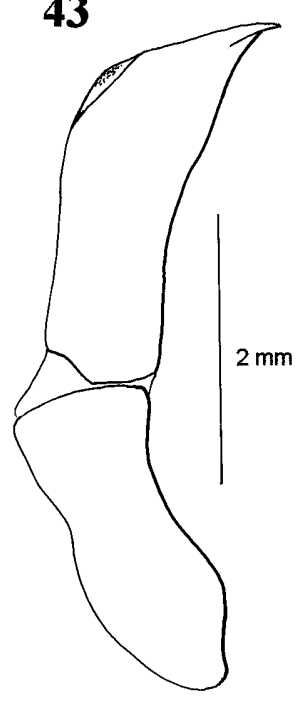

42

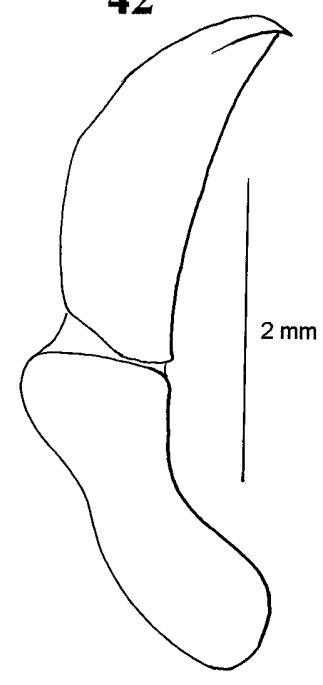

44

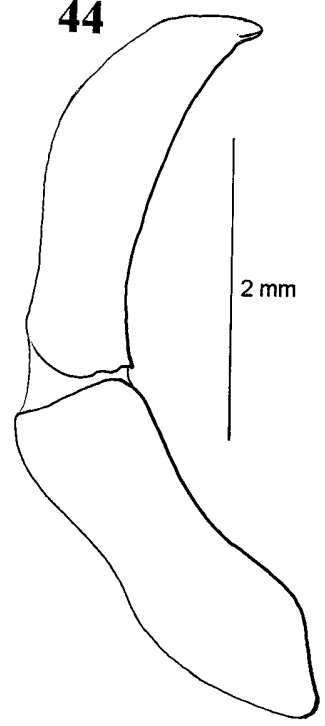

45

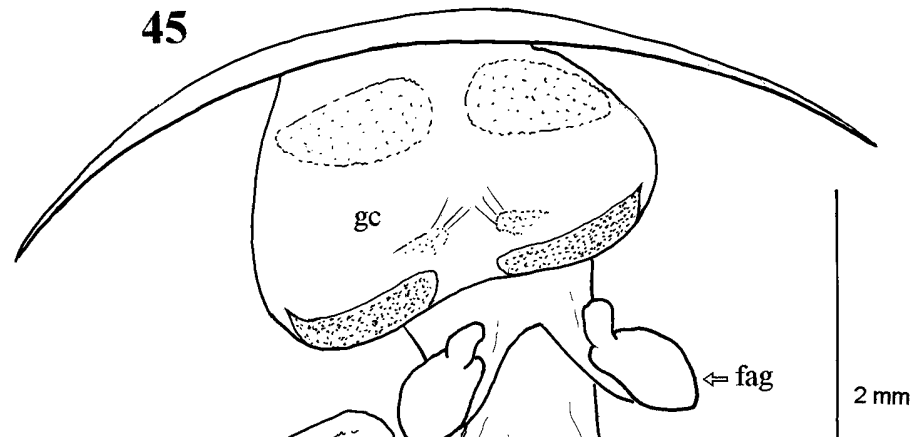

Figs 41-45. Morphology of Amphimallon. 41-44: Aedeagus (lateral view). 41 - A. atrum; 42 - A. nigripenne; 43 - A. ochraceum; $44-A$. fissiceps. 45: Female genital structure of $A$. seidlitzi (bc - bursa copulatrix; fag - female accesory glands; gc - genital chamber; ov - oviduct; sp - spermatheca; spg - spermatecal gland, spi - spicules area).

which seems rough, by its colour pattern, and by its smaller size.

\section{Amphimallon safiense sp. $\mathbf{n}$.}

Description. Length: $12-13 \mathrm{~mm}$. Basic colour yellowbrown, head, pronotum and elytra red-brown.

Head (Fig. 16). Clypeus enlarged, its edge weakly raised. Clypeus and frons with fine and very dense punctation which bears long hair-like setae. Frons without carina. Antennae 9-segmented, club shorter than the other segments together.

Pronotum. Surface of tegument smooth or scarcely microreticulated. Punctation fine and dense, irregular with very long hair-like setae. Basal margin thin. Edge regularly curved.

Elytra. Odd interstriae indistinctly elevated. Punctation fine and dense, odd interstriae more sparsely punctured.
Surface clothed with very short hardly visible setae on disc, clearly longer around scutellum.

Pygidium. Punctuation superficial, regularly spaced. Surface clothed with hardly perceptible short and inclined setae.

Legs. Protibiae tridentate.

Aedeagus (Figs 12-13) and endophallus (Fig. 14).

Female unknown.

Type material. Holotype: $1 \delta$ Morocco, Safi (MNHN). Paratypes: $2 \partial$, same data (MNHN).

Etymology. Species named after its occurrence in Safi.

Remarks. Amphimallon safiense sp. $\mathrm{n}$. is close to Amphimallon litigiosum Fairmaire, 1860, with which it was until now confused. Both species can be separated by the punctation, by the pilosity of the head and pronotum, and by the shape of endophallus which is very particular in A. safiense sp. n. (Fig. 14). 
TABLE 2. Character comparisons to separate Amphimallon jeannae sp. n. from Amphimallon theryi Peyerimhoff.

\begin{tabular}{|c|c|c|}
\hline & Amphimallon theryi Peyerimhoff & Amphimallon jeannae sp. $\mathrm{n}$. \\
\hline Shape of clypeus & Narrow, sinuated in the middle (Fig. 23) & Wide, semicircular (Fig. 21) \\
\hline Frontal relief & $\begin{array}{l}\text { Straight transverse carina, interrupted } \\
\text { in the middle (Fig. 23) }\end{array}$ & $\begin{array}{l}\text { Two short transversal elevations placed on a central } \\
\text { gibbosity (Fig. 21) }\end{array}$ \\
\hline Punctation of pronotum & $\begin{array}{l}\text { Superficial, points feebly rough on their front } \\
\text { margin (Fig. 23) }\end{array}$ & Strong and deep, denser (Fig. 21) \\
\hline Shape of pronotum & $\begin{array}{l}\text { Feebly convex in lateral view (Fig. 24); the sides } \\
\text { regularly curved in dorsal view (Fig. 23) }\end{array}$ & $\begin{array}{l}\text { More convex in lateral view (Fig. 22); more transverse, } \\
\text { with less regularly curved, more angular sides in dorsal } \\
\text { view (Fig. 21) }\end{array}$ \\
\hline Shape of elytra & Widened before apex & Subparallel \\
\hline Aedeagus & Parameres shorter than phallobasis (Fig. 28) & Parameres at least as long as the phallobasis (Fig. 25) \\
\hline Endophallus & Regular body (Fig. 30) & $\begin{array}{l}\text { Body strongly constricted before lateral apical saccules } \\
\text { (Fig. 27) }\end{array}$ \\
\hline
\end{tabular}

\section{Amphimallon maniense sp. n.}

Description. Habitus as in Fig. 17. Length: 16-17.5 mm. Robust body shape. Basic colour yellow-brown to pale red-brown, pronotum with large, vague, dark brown flecks. Elytra pale red-brown. Clypeus, legs, sterna and pygidium yellow-brown. Disc of sterna darkened. Edge of clypeus black.

Head. Clypeus wide, its edge raised, straight or feebly sinuate in middle. Frons without transverse carina. Antennae 9-segmented, club shorter than the other segments together.

Pronotum. Posterior part with a feeble median furrow. Surface of tegument smooth or scarcely microreticulated. Punctation double, large points mixed with smaller points, regularly distributed and dense, spaced by less than one diameter. Hair-like setae are short but regularly distributed and clearly perceptible. Basal margin enlarged, but thinner in front of scutellum.

Elytra. Odd interstriae elevated, with fine transversal ridges. Meso- and metasternum clothed with long pale setae.

Legs. Protibiae tridentated, basal tooth obsolete. Median tarsi short and thick.

Aedeagus (Figs 18-19) and endophallus (Fig. 20).

Female unknown.

Type material. Holotype: ô, 29.v.1995, Greece, Peloponnese, Máni Kita, J.-M. Maldès leg. (MNHN). Paratypes: 15 , same data ( 2 specimens collected by S. Doguet and 3 by $\mathrm{F}$. Duhaldeborde), in collections of MNHN, J.M. Maldès and F. Duhaldeborde.

Etymology. Species named after its occurrence in Máni.

Remarks. The specimens were collected during the evening flight, above the ground level of a grassland.

\section{Amphimallon jeannae sp. $\mathbf{n}$.}

Description. Length: 12-13.5 mm. Basic colour dark red-brown to black, reddish brown elytra.

Head (Fig. 21). Frons hairy, armed with two paramedian transverse elevations on a central gibbosity which do not reach. Semicircular clypeus, with regularly lifted borders. Antennae 9-segmented, club shorter than the other segments together.

Pronotum. Convex and transverse, with barely angular, curved sides. Basal margin thin. Surface of tegument microreticulated. Punctation dense, double: size of punc- tures is irregular. Punctures spaced by one diameter. Surface clothed with long golden hair-like setae.

Elytra. 1st and 3rd interstriae feebly elevated. Punctation fine and dense, odd interstriae more sparsely punctured. Surface clothed with very short setae on disc, clearly longer around scutellum.

Pygidium. With a superficial punctation, punctures regularly spaced. Clothed with very short and inclined setae, hardly perceptible.

Legs. Protibiae tridentate. Metatarsi remarkably long and thin.

Aedeagus (Figs 25-26) and endophallus (Fig. 27).

Female unknown.

Type material. Holotype: §, Morocco, Zaers (MNHN). Paratypes: $1 \delta$, same data; $3 \delta$, Morocco, Rabat (MNHN).

Etymology. Species named after Jeanne Charbonnel for her important work in the Melolonthidae collections in MNHN

Remarks. This species is close to Amphimallon theryi Peyerimhoff, 1949 with which it was until now confused. Both species could be separated by the characters in Table 2.

\section{CONCLUSION}

Phylogenetic analysis of the genus Amphimallon Berthold based on a study of morphological characters enabled systematic conclusions, in particular the redescription of the Amphimallon s. str. and the definition of the main groups of this genus. Position of seven species previously included in Amphimallon is questioned. Phylogenetic hypothesis for a group allows also to propose evolutionary scenarios in biogeography and biology, and this is intended for Amphimallon in forthcoming papers.

ACKNOWLEDGEMENTS. I am grateful to Y. Cambefort for giving helpful comments and suggestions on the manuscript. I wish to thank the curators who lent type material, F. Duhaldeborde, S. Doguet and J.-M. Maldès for the permission to study study their material from Greece, and C. Daugeron and P. Grandcolas for their critical reading of this paper. Special acknowledgement is due to M. Orliac for drawing the habitus of Amphimallon maniense sp. $\mathrm{n}$.

\section{REFERENCES}

BÁguenA L. 1959: Los Rhizotrogina ibericos (Coleoptera: Melolonthidae: Melolonthinae). Graellsia 17: 93-102. 
Báguena L. 1967: Scarabaeoidea de la faune Ibero-Balear y Pirenaica. Consejo superior de investigaciones cientificas, Institut español de entomologia, Madrid, $576 \mathrm{pp}$.

BARAUD J. 1967: Les Rhizotrogus du "groupe pini" (Coleoptera: Melolonthidae: Melolonthinae). Description d'une nouvelle espèce d'Espagne. Bull. Soc. Entomol. Fr. 72: 39-44.

BARAUD J. 1977a: Aberrations antennaires et taxonomie chez les Melolonthidae. Nouv. Rev. Entomol. 7: 315-320.

Baraud J. 1977b: Coléoptères Scarabaeoidea. Faune de l'Europe Occidentale. Publication de la Nouvelle Revue d'Entomologie, IV. Université Paul Sabatier, Toulouse, 352 pp.

BARAUD J. 1981: Coléoptères Scarabaeoidea nouveaux ou intéressants de la faune ibérique. Nouv. Rev. Entomol. 11: 271-276.

BARAUD J. 1985: Coléoptères Scarabaeoidea, Faune du Nord de l'Afrique, du Maroc et du Sinaï. Encyclopédie Entomologique XLVI. Lechevalier, Paris, $652 \mathrm{pp}$

BARAud J. 1992: Coléoptères Scarabaeoidea d'Europe. Faune de France 78. Fédération française des Sociétés de Sciences naturelles, Paris, and Société Linnéenne, Lyon, $856 \mathrm{pp}$.

CARAYon J. 1951: Procédé d'étude anatomique de certains organes internes chez des insectes desséchés. Feuille Nat. (N.S.) 6: 89-93.

CARAYON J. 1969: Emploi du noir chlorazol en anatomie microscopique des insectes. Ann. Soc. Entomol. Fr. (N.S.) 5: 179-193.

COCA ABIA M. 1995: Taxonomía, filogenia y biogeografia del género Rhizotrogus en el Metiterráneo Occidentale (Coleoptera: Melolonthidae: Melolonthinae). Universidad Complutense de Madrid, unpublished thesis, $290 \mathrm{pp}$.

Coca Abia M. \& Martín Piera F. 1998: Revisión taxonómica del género Rhizotrogus Berthold, 1827. Coleopterological Monographs 2. European Association of Coleopterology, Barcelona, $140 \mathrm{pp}$

CRISCI J.V. 1982: Parsimony in evolutionary theory: Law or methodological prescription? J. Theor. Biol. 97: 35-41.

Darlu P. \& Tassy P. 1993: Reconstitution phylogénétique. Concepts et méthodes. Collection Biologie Théorique 7. Masson, Paris, $245 \mathrm{pp}$.

Forey P.L., Humphries C.J., Kitching I.J., Scotland R.W., SieBERT D.J. \& Williams D.M. 1992: Cladistics. A pratical course in systematics. The Systematics Association Publication No. 10. Oxford University Press, Oxford, $191 \mathrm{pp}$.

Gambrell F.L. 1946: The European Chafer Amphimallon majalis and its control in lawns. J. Econ. Entomol. 39: $168-173$

Gambrell F.L., Mendall S.C. \& Smith E.H. 1942: A destructive European insect new to the United States. J. Econ. Entomol. 35: 289

Maddison W.P. \& Maddison D.R. 1993: MacClade: Analysis of phylogeny and character evolution. Version 3.04. Sinauer Associates Inc., Sunderland, MA

Martín Piera F. 1985: Los géneros de Melolonthini y las especies íbero-baleares de Amphimallon Berthold, 1827 y Monotropus Erichson, 1848 (Coleoptera: Melolonthidae). Graellsia 41: $7-30$.

Medvedev S.I. 1951: Fauna SSSR. Coleoptera, X, 1. Academy of Sciences of the USSR, Moscow, 513 pp. (in Russian).

Mrksic R. 1970: Katalog der Lamellicornia jugoslawiens. Institut Za Sumarstvo, Sarajevo, $71 \mathrm{pp}$

MontREurL O. 1997: Amphimallon menorcanum Reitter, 1902 , nouveau synonyme de Rhizotrogus pallidipennis Blanchard, 1850 (Coleoptera: Melolonthidae: Melolonthinae). Boll. Soc. Hist. Nat. Balears 40: 147-149.

Montreull O. 1999: Révision de deux espèces de Grèce du genre Amphimallon Berthold, 1827 (Coleoptera: Melolonthi- dae) et description d'une nouvelle espèce. Bull. Soc. Entomol. Fr. 104: 105-108.

Nikolajev G.V. 1987: Fauna of Kazakhstan and Central Asia. Nauka, Alma Ata, $232 \mathrm{pp}$.

Nixon K.C. \& Carpenter J.M. 1993: On outgroup. Cladistics 9: 413-426.

RÉGNIER R. 1939: Contribution à l'étude des Hannetons. Un grand ennemi des gazons: Amphimallon majalis Razoumowsky (Coleoptera: Melolonthidae: Melolonthinae). Ann. Epiphyt. Phytogénét. 5: 257-265.

RÉGNIER R. 1940: Contribution à l'étude de la biologie d'Amphimallon majalis Razoumowsky (= rufescens Latr.), ravageur des gazons (Coleoptera: Melolonthidae: Melolonthinae). VI congreso Internacional de Entomologia, Madrid (1935). Museo Nacional de Ciencias Naturales, Madrid, pp. 730-736.

ReITTER E. 1902: Bestimmungs-Tabelle der Melolonthidae aus der europäischen Fauna und den angrenzenden Ländern, enthalten die Gruppen der Pachydemini, Sericini und Melolonthini. Verh. Naturf. Ver. Brünn 40: 94-303.

SchinardT H.H. \& WithComb W.H. 1943: Life history of the European Chafer Amphimallon majalis (Razoumowsky) (Coleoptera: Melolonthidae: Melolonthinae). J. Econ. Entomol. 36: 345-346.

SHOREY H.H. \& GYrisco G.G. 1960: Effects of soil temperature and moisture on the vertical distribution of European Chafer larvae. Ann. Entomol. Soc. Am. 53: 666-670.

Swofford D.L. 1992: PAUP: Phylogenetic Analysis Using Parsimony. Version 3.1. Illinois Natural History Survey, Champaign.

WrLeY E.O. 1981: Phylogenetics. The Theory and Practice of Phylogenetic Systematics. John Wiley, New York, 439 pp.

Appendix 1. Synonymical list of taxa belonging to Amphimallon Berthold, 1827 sensu auctorum. Names of species not considered in the phylogenetic analysis are marked with *. Species excluded from Amphimallon s.str. are in square brackets.

Amphimallon adanense sp. $\mathrm{n}$.

Amphimallon alatavicum Medvedev, 1951

[Amphimallon altifrons Baraud, 1971]

Amphimallon altaicum (Mannerheim, 1825)

= Monotropus suwortzewi Semenov, 1891

[Amphimallon amphibolum Peyerimhoff, 1949]

Amphimallon arianae (Fairmaire, 1879) (see Montreuil, 1999)

Amphimallon assimile (Herbst, 1790)

$=$ Melolontha aprilina Duftschmidt, 1805

= Rhizotrogus neapolitanus Brenske, 1902

var. fulvicolle Erichson, 1848

var. obscurum Brenske, 1890

Amphimallon atrum (Herbst, 1790)

= Melolontha fusca Olivier, 1789

$=$ Rhizotrogus (Amphimallus) nomadicus Reiche, 1862

Amphimallon brucki (Fairmaire, 1879)

Amphimallon burmeisteri Brenske, 1886

$=$ Rhizotrogus pilicollis Burmeister, 1855 nec Gyllenhal

= Rhizotrogus (Amphimallon) assimilis ssp. bonadonai Paulian, 1959

Amphimallon cantabricum Heyden, 1870

= Amphimallus Felicitanus Reitter, 1902

var. trichroum Reitter, 1907

*Amphimallon circassicum Brenske, 1894

Amphimallon circumligatum (Peyerimhoff, 1949)

*Amphimallon crinitum Brenske, 1894

Amphimallon evorense Reitter, 1913

Amphimallon fissiceps Fairmaire, 1860

Rhizotrogus obtusilobus Fairmaire, 1879 
Amphimallon furvum Germar, 1817 stat. $\mathrm{n}$. Amphimallon fuscum (Scopoli, 1786)

= Amphimallus logesi Mulsant, 1872

$=$ Rhyzotrogus Nebrodensis Ragusa, 1881

var. sirentense Leoni, 1906

Amphimallon gianfranceschii Luigioni, 1931

Amphimallon insculptum Brenske, 1889

*Amphimallon irtishense Nikolajev, 1979

Amphimallon javeti Stierlin, 1864 stat. $\mathrm{n}$.

*Amphimallon jedlickai Balthasar, 1936

Amphimallon jeannae sp. $\mathrm{n}$.

Amphimallon jeannei (Baraud, 1971) comb. $\mathrm{n}$.

[Amphimallon julieni (Baraud, 1972)]

Amphimallon leuthneri Brenske, 1902

Amphimallon litigiosum Fairmaire, 1860

= Rhizotrogus semivillosus Fairmaire, 1883

$=$ Amphimallon gallet $i$ Baraud, 1970 syn. $\mathrm{n}$.

Amphimallon lusitanicum (Gyllenhal, 1817)

= Monotropus angulicollis Fairmaire, 1859

Amphimallon maevae Montreuil, 1999

Amphimallon majale (Razoumowsky, 1789)

= Melolontha rufescens Latreille, 1802

= Melolontha Semi-rufa Gyllenhal, 1817

var. pellitulum Reitter, 1902

var. korbi Reitter, 1894

Amphimallon maniense sp. $\mathrm{n}$.

[Amphimallon melillanum (Baraud, 1972)]

Amphimallon menori Baguena, 1955

Amphimallon mussardi (Antoine, 1959)

Amphimallon naceyroi Mulsant, 1859

Amphimallon nigripenne Reitter, 1902

Amphimallon nigrum (Waltl, 1835)

$=$ Rhizotrogus Flavicornis Blanchard, 1850

ssp. ebenimum Baraud, 1973

Amphimallon obscurum Reiche, 1864

$=$ Rhizotrogus brunneus Fairmaire, 1870

var. albipile Reitter, 1902

Amphimallon occidentale Petrovitz, 1964

Amphimallon ochraceum (Knoch, 1801)

*Amphimallon pardoi Baraud, 1971

Amphimallon peropacum Reitter, 1911

$=$ Rhizotrogus (Amphimallon) peropacus Baraud, 1972

Amphimallon pini (Olivier, 1789)

var. bicolor Mulsant, 1842

var. ustulatipenne Mulsant, 1842

var. diluticolle Baraud \& Tauzin, 1987

Amphimallon pseudomajale Sabatinelli, 1976

Amphimallon pygiale Mulsant, 1846

Amphimallon roris Baraud, 1981

Amphimallon ruficorne (Fabricius, 1775)

= Melolontha Marginata Herbst, 1784

= Melolontha pagana Olivier, 1789

Amphimallon safiense sp. $\mathrm{n}$.

Amphimallon sainzii (Graëlls, 1858)

[Amphimallon scutellare (Lucas, 1846)]

$=$ Rhizotrogus (Amphimallus) lobatus Fairmaire, 1860

$=$ Rhizotrogus parallelus Fairmaire, 1860

= Rhizotrogus cristatifrons Fairmaire, 1883

$=$ Rhizotrogus marginiceps Fairmaire, 1866

$=$ Rhizotrogus warioni Marseul, 1878

Amphimallon seidlitzi Brenske, 1891

$=$ Melolontha limbatipennis Villa, 1833

= Amphimallus trisinuatus Reitter, 1902 syn. n.

*Amphimallon semenovi Medvedev, 1951

*Amphimallon sithoniense Král, 1998

Amphimallon solstitiale (Linné, 1758)
= Scarabaeus autumnalis Geoffroy, 1785

= Rhizotrogus subsulcatus Falderman, 1835

ssp. dalmatinum Brenske, 1894

var. fallenii Gyllenhal, 1817

var. aurantiacum Mulsant, 1842

var. fulvicolle Mulsant, 1842

var. laterale Mulsant, 1842

var. suturale Mulsant, 1842

ssp. grossatum Eschscholtz, 1902

ssp. javeti Stierlin, 1864

ssp. mesasiaticum Medvedev, 1951

var. anthracinum Medvedev, 1951

var. montivagum Halbherr, 1892

ssp. orientale Brenske, 1902

ssp. parumsetosum Medvedev, 1951

ssp pictum Kraatz, 1902

var. pineticola Graëlls, 1858

ssp. setosum Brenske, 1902

ssp. sibiricum Brenske, 1902

var. simplicissimum Müller, 1902

ssp. tropicum Gyllenhal, 1817

ssp. matutinale Nonveiller, 1963

Amphimallon spartanum (Brenske, 1884)

[Amphimallon subcristatum (Fairmaire, 1879)]

[Amphimallon subparallelum (Escalera, 1913)]

*Amphimallon suturale Lucas, 1859

*Amphimallon tanyproctoides Reitter, 1906

var. nigripenne Petrovitz, 1964

Amphimallon theryi Peyerimhoff, 1949

Amphimallon vernale (Brullé, 1832) stat. $\mathrm{n}$.

$=$ Rhizotrogus torulosus Waltl, 1838

= Amphimallon medvedevi Iablokov-Khnzorian, 1955

var. schiraziense Brenske, 1902

ssp. persicum Petrovitz, 1970

Amphimallon verticale (Burmeister, 1855)

Amphimallon vitalei Luigioni, 1932

Amphimallon vivesi Baraud, 1967

Amphimallon volgense (Fischer, 1823)

= Melolontha caspica Ménétries, 1832

Amphimallon vulpecula (Peyerimhoff, 1931)

Appendix 2. List of morphological characters.

1. Head: (0) of moderate size; (1) strongly enlarged.

2. Clypeus: (0) short; (1) enlarged (Fig. 21).

3. Edge of clypeus: (0) feebly raised, the clypeus feebly concave; (1) clypeus bilobate, strongly raised only in the corners (Fig. 15); (2) strongly raised all around, the clypeus deeply concave.

4. Clypeus: (0) without setae or with scattered setae only in the corners; (1) with long, raised hair-like setae.

5. Clypeus and cephalic capsule: (0) with the same colour, sometimes the clypeus slightly lighter; (1) head bicoloured, clypeus yellow-brown, cephalic capsule brown or black.

6. Frons of male: (0) without or with only a feeble, indistinct transverse elevation (Figs 1-2); (1) with a strong transverse carina which reaches the sides of the head (Figs 3, 15); (2) with two paramedian transverse tubercles which do not reach the sides of the head.

7. Frons of female: $(0)$ without or with a feeble, indistinct transverse carina; (1) with a strong transverse carina.

8. Antenna: (0) 10-segmented (Fig. 1); (1) 9-segmented (Figs 2, 3); (2) 8-segmented.

9. Antennal club: (0) short, its segments shorter than the other segments together (Figs 1, 3); (1) long, its segments, curved 
before apex, clearly longer than the other segments together (Fig. 2).

10. Sensillar area of inner side of first antennal club segment: (0) limited to this inner side (Fig. 31); (1) prolonged and developed on the outer side basis (Fig. 32).

11. Second antennal club segment: (0) with only the dorsal margin smooth, the ventral margin with area of sensilla (Fig. 32); (1) with ventral and dorsal margins smooth, both without sensilla area (Fig. 31).

12. Eyes of male: $(0)$ of moderate size, together less than half of head width in ventral view; (1) strongly enlarged, together two thirds of head width in ventral view.

13. Dorsal side of labium: (0) with two paramedian lines of short and dense setae (Fig. 33); (1) without lines of setae (Fig. 34).

14. Postmentum: (0) present; (1) absent.

15. Punctation of the outer side of mandible: (0) strongly marked; (1) fine and superficial, hardly perceptible.

16. Apical segment of labial palp: (0) narrow or feebly enlarged; (1) strongly inflated.

17. Pronotum: (0) less than twice as wide as long; (1) transverse, at least twice as wide as long.

18. Anterior part of lateral edge of pronotum: (0) straight or regularly convex; (1) feebly sinuate.

19. Posterior part of lateral edge of pronotum: (0) straight or regularly convex; (1) sinuate.

20. Anterior part of lateral edge of pronotum: (0) not raised; (1) distinctly raised.

21. Anterior part of lateral edge of pronotum: (0) crenellated; (1) not crenellated

22. Basal margin of pronotum: (0) thin; (1) enlarged.

23. Pronotal disc: $(0)$ without or with a feeble impression in front part; (1) with a median furrow at least in the posterior part.

24. Tegument of pronotum: (0) smooth; (1) microreticulated.

25. Main punctation of pronotum: (0) quite irregular, more or less dense; (1) double, large points mixed with predominant smaller points; (2) quite fine, dense and regular.

26. Pronotum: (0) with only large punctation; (1) with very fine punctation without setae between large points.

27. Hair-like setae of pronotum: (0) short or long, but well developed on entire surface; (1) lacking at least in front part and on the sides of the disc.

28. Hair-like setae of pronotum: (0) long; (1) short, sometimes hardly perceptible.

29. Sides of pronotum: $(0)$ without inclined short setae or with regularly inclined short setae present also on the disc; (1) with irregularly inclined short setae which may form an irregular white fleck.

30. Prosternal basisternum: (0) large and flat; (1) narrow, with a transversal furrow.

31. Disc of pronotum: $(0)$ with the same tint as the sides, or slightly darker; (1) black or dark brown, presenting an evident contrast with the yellowish sides; (2) only with irregular dark maculae.

32. Pronotum and elytra: (0) with the same colour; (1) pronotum slightly darker than dark reddish-brown elytra; (2) pronotum paler than elytra; (3) pronotum darker than yellowish-brown elytra; (4) pronotum darker than pale reddish-brown elytra.

33. Metasternum: (0) with only hair-like setae; (1) with robust spinose setae in addition to the hair-like setae.

34. Elytra: (0) not or weakly expanded; (1) clearly laterally expanded in the front part

35 . Fifth odd interstria of elytra: (0) not or vaguely elevated; (1) clearly elevated like the other odd interstriae.
36. Surface of odd elytral interstriae: (0) only punctuated, sometimes with transversal rough ridges, but the punctation is clearly visible; (1) with fine transversal ridges which generally conceal the punctation.

37. Elytral disc: (0) glabrous; (1) with short but clearly perceptible setae, dense and regularly distributed; (2) with long sparse setae; (3) with very short hardly perceptible setae; (4) with quite long and inclined, regularly distributed setae; (5) with long and inclined, irregularly distributed setae.

38. Posterior margin of first visible sternum: (0) straight; (1) $\mathrm{V}$-shaped in the middle.

39. Sterna: (0) totally yellowish-brown to reddish-brown; (1) yellowish-brown with only the disc dark reddish-brown, except for the last sternum.

40. Sterna: (0) without or with sparse inclined short setae; (1) with dense inclined short setae which form white flecks at least on the sides.

41. Pygidium: (0) with superficial and irregular sparse punctation; (1) with regular and dense punctation.

42. Pygidium: (0) with very short, hardly perceptible setae; (1) with short and inclined setae; (2) with very long and raised setae; (3) with short, but clearly perceptible, raised setae.

43. Pygidium and sterna: (0) with the same colour; (1) pygidium totaly darkened, darker than the sterna; (2) pygidium with only a median dark macula.

44. External edge of protibiae: (0) tridentate, the teeth equidistant; (1) tridentate, the median tooth close to the basal; (2) unidentate.

45. Tridentate external edge of female protibiae: $(0)$ thin, not enlarged; (1) strongly enlarged.

46. Metatibiae: (0) without spurs on the dorsal edge; (1) with spurs.

47. Inner spur of protibiae: $(0)$ inserted at or slightly before the level of the median tooth on outer edge; (1) clearly inserted between median and apical teeth.

48. Superior spur of metatibiae: (0) uniformly thin; (1) enlarged before apex.

49. Ventral edge of second tarsomere of protarsus: (0) not dentate; (1) clearly and strongly dentate.

50. Ventral edge of claw: (0) with a basal tooth (Fig. 35); (1) without a basal tooth (Fig. 36).

51. Endosymbiotic crypts in male mesenteron: $(0)$ present, well developed; (1) present, feebly developed; (2) absent.

52. Parameres, in dorsal view: (0) not or weakly inflated (Figs 37-38); (1) clearly inflated (Fig. 40).

53. Parameres, in lateral view: (0) thin; (1) thick (Fig. 39).

54. Parameres, in lateral view: (0) weakly simuated before apex (Figs 39, 41); (1) regularly curved (Figs 42-43); (2) straight and elongated (Fig. 44).

55. Apex of parameres, in lateral view: (0) feebly salient or truncated (Figs 39, 44); (1) clearly inflated (Fig. 41); (2) with a small curved tooth toward ventral side (Fig. 42); (3) blunted (Fig. 43).

56. Apex of parameres, in dorsal view: (0) regular (Fig. 37); (1) with an internal concavity (Fig. 38).

57. Dorsal side of parameres: (0) smooth; (1) with a subapical area of spicules (Fig. 44).

58. Width of ventro-median subapical non-sclerotized area of parameres: (0) wide; (1) narrow.

59. Ventro-median subapical non-sclerotized area of parameres: (0) regularly delimited laterally; (1) irregularly delimited laterally.

60. Dorso-median non sclerotized area of parameres basally: $(0)$ wide, half of the width of parameres together; (1) narrow, as wide as a third of the width of parameres together. 
61. Sclerotized apophyses of endophallus: (0) well developed, thick and longer than half the length of endophallus (Fig. 4); (1) absent; (2) feebly developed, thin, shorter than a third of the length of endophallus (Fig. 5).

62. Basis of endophallus dorsally: (0) regular; (1) with two paramedian saccules.

63. Basis of endophallus dorsally: (0) without a clearly differentiated area of spicules; (1) with a dense area of spicules which expands basally on the sides; (2) with a dense area of spicules which does not expand basally on the sides.

64. Ventro-median area of spicules of endophallus: (0) not clearly delimited; (1) clearly delimited, the front part M-shaped; (2) absent.

65. Basis of the inner side of bursa copulatrix: $(0)$ with an area of spicules (Fig. 45); (1) without an area of spicules.

Appendix 3. List of unambiguous character changes

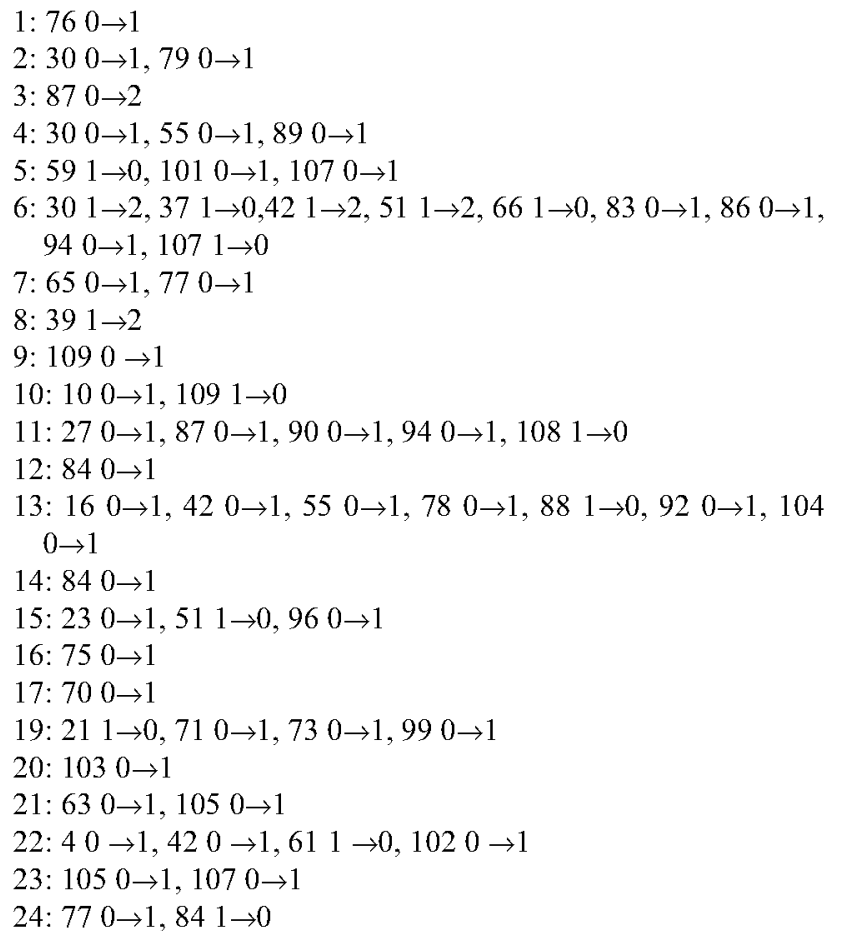

$25: 700 \rightarrow 1,990 \rightarrow 2,1050 \rightarrow 2,1070 \rightarrow 2$

26: $720 \rightarrow 1,1080 \rightarrow 1$

27: $401 \rightarrow 0,710 \rightarrow 1,740 \rightarrow 1,1080 \rightarrow 1$

28: $290 \rightarrow 1,420 \rightarrow 1,810 \rightarrow 1,1050 \rightarrow 1$

29: $270 \rightarrow 1,690 \rightarrow 1,980 \rightarrow 1$

30: $700 \rightarrow 1,750 \rightarrow 1$

$31: 591 \rightarrow 0,1010 \rightarrow 2,1060 \rightarrow 2$

32: $110 \rightarrow 3,16 \quad 0 \rightarrow 3,18 \quad 0 \rightarrow 1,41 \quad 0 \rightarrow 1,43 \quad 0 \rightarrow 4,85 \quad 0 \rightarrow 1,87$ $1 \rightarrow 4,911 \rightarrow 3,1060 \rightarrow 2$

33: $940 \rightarrow 1$

34: $310 \rightarrow 1,400 \rightarrow 1,800 \rightarrow 1$

35: $1070 \rightarrow 1$

36: $1070 \rightarrow 1$

37: $28 \quad 5 \rightarrow 2,354 \rightarrow 3,693 \rightarrow 1,823 \rightarrow 5,883 \rightarrow 4,1065 \rightarrow 3,98$ $3 \rightarrow 2$

38: $950 \rightarrow 1$

39: $530 \rightarrow 1,591 \rightarrow 0,990 \rightarrow 1,1070 \rightarrow 1$

40: $900 \rightarrow 1$

41: $680 \rightarrow 1$

$42: 280 \rightarrow 2,400 \rightarrow 3,690 \rightarrow 3,980 \rightarrow 2,990 \rightarrow 3$

43: $210 \rightarrow 1,1060 \rightarrow 1$

44: $490 \rightarrow 2,561 \rightarrow 2,1020 \rightarrow 1,1061 \rightarrow 0,1101 \rightarrow 0$

45: $1030 \rightarrow 1$

46: $280 \rightarrow 1$

47: $930 \rightarrow 1$

48: $210 \rightarrow 1,400 \rightarrow 1,800 \rightarrow 1$

49: $700 \rightarrow 1,750 \rightarrow 1$

50: $400 \rightarrow 1,840 \rightarrow 1$

$51: 110 \rightarrow 1,170 \rightarrow 1,51 \quad 1 \rightarrow 2,561 \rightarrow 0,892 \rightarrow 1$

52: $740 \rightarrow 1$

53: $100 \rightarrow 1,740 \rightarrow 1,990 \rightarrow 1$

$54: 40 \quad 0 \rightarrow 1,970 \rightarrow 2,1040 \rightarrow 1$

$55: 100 \rightarrow 3,400 \rightarrow 2,512 \rightarrow 3,840 \rightarrow 3,900 \rightarrow 1,1030 \rightarrow 2$

56: $970 \rightarrow 1$

57: $210 \rightarrow 1,910 \rightarrow 1,1000 \rightarrow 1$

$58: 8 \quad 0 \rightarrow 1,720 \rightarrow 1,90 \quad 0 \rightarrow 1,930 \rightarrow 1,102 \quad 1 \rightarrow 0$

59: $391 \rightarrow 0,900 \rightarrow 1$

62: $640 \rightarrow 1$

63: $720 \rightarrow 2$

64: $220 \rightarrow 2,700 \rightarrow 1,1050 \rightarrow 2$

65: $331 \rightarrow 0$

Received April 21, 1999; accepted February 7, 2000 